Keywords: Tank Closure

Concrete

Retention: Permanent

\title{
Tanks 18 and 19-F Structural Flowable Grout Fill Material Evaluation and Recommendations
}

\author{
D. B. Stefanko \\ C. A. Langton
}

April 2013

Savannah River National Laboratory Savannah River Nuclear Solutions, LLC Aiken, SC 29808

Prepared for the U.S. Department of Energy under contract number DE-AC09-08SR22470.

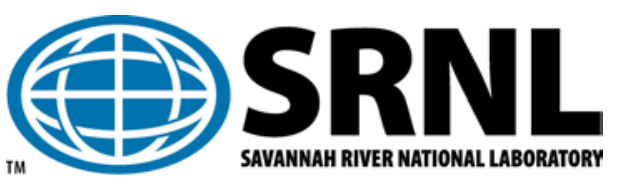


SRNL-STI-2011-00551

Revision 1

\section{DISCLAIMER}

This work was prepared under an agreement with and funded by the U.S. Government. Neither the U.S. Government or its employees, nor any of its contractors, subcontractors or their employees, makes any express or implied:

1. warranty or assumes any legal liability for the accuracy, completeness, or for the use or results of such use of any information, product, or process disclosed; or

2. representation that such use or results of such use would not infringe privately owned rights; or

3. endorsement or recommendation of any specifically identified commercial product, process, or service.

Any views and opinions of authors expressed in this work do not necessarily state or reflect those of the United States Government, or its contractors, or subcontractors.

\section{Printed in the United States of America}

Prepared for

U.S. Department of Energy 


\section{REVIEWS AND APPROVALS}

\section{AUTHORS:}

C. A. Langton, E\&CPT Research Programs

Date

D. B. Stefanko, E\&CPT Research Programs

Date

TECHNICAL REVIEW:

M. G. Serrato, E\&CPT Research Programs / SRNL

Date

\section{APPROVAL:}

H. H. Burns, E\&CPT Research Programs, Project Manager

Date

F. M. Pennebaker, AC\&P, Manager

Date

S. L. Marra, E\&CPT Research Programs, Manager

Date

R. C. Jolly, Jr., FY11 Closure Project Engineering, SRR, Manager

Date

P. E. Carroll, FY12 Closure Project Engineering, SRR, Manager

Date

J. E. Herbert, SRR Project Operations, Manager

Date

B. A. Martin, Closure and Disposal Determination, SRR

Date 
SRNL-STI-2011-00551

Revision 1

\section{ACKNOWLEDGEMENTS}

URS Washington Group, Quality and Testing Division management and technical personnel provided use of the SRS Civil Engineering Laboratory and test equipment, and technical expertise and input that was essential for performing the tests and obtaining the results in this report. W. Pope, Jr., W. B. Mhyre, and J. T. Waymer, URS, are recognized as key contributors to this project.

J. L. Steimke, H. N. Guerrero, and M. L. Restivo, SRNL Engineering Development, provided the thermal properties for selected mixes. This information was required for designing the tank fill grout formulation. H. N. Guerrero also designed the instrumented shrinkage characterization test forms and designed the test protocol for measuring dimensional changes of the tank fill grout as a function of temperature, time, and relative humidity. This effort supports designing tank fill grouts that minimize fast pathways (cracks and gaps) inherent to conventional cementitious materials.

K. L. Dixon provided moisture retention data needed to calculate relative hydraulic conductivities (as a function of saturation). J. T. Mason, Jr., SRNS Geotechnical Engineering, is the STR for the MACTEC contract and provided an efficient interface with MACTEC. 


\section{LIST OF REVISIONS}

\begin{tabular}{|c|c|c|}
\hline $\begin{array}{l}\text { Revision } \\
\text { Number }\end{array}$ & Summary of Changes & Date \\
\hline 1 & $\begin{array}{l}\text { Revision was made to Table } 3-6 \text {, page } 20 \text {. An error was identified in } \\
\text { the Revision } 0 \text { results provided by MACTEC in Test Report for } \\
\text { Project No. } 6155-08-0031 \text { Revision 0. The error was corrected in by } \\
\text { MACTEC in Test Report for Project No. } 6155-08-0031 \text { Revision } 1 \text { and } \\
\text { in the text of this report but not in Table 3-6. Table 3-6 on page } 20 \text { has } \\
\text { been corrected. }\end{array}$ & $4 / 23 / 2013$ \\
\hline & & \\
\hline & & \\
\hline
\end{tabular}


SRNL-STI-2011-00551

Revision 1

\section{EXECUTIVE SUMMARY}

Cementitious grout will be used to close Tanks 18-F and 19-F. The functions of the grout are to: 1) physically stabilize the final landfill by filling the empty volume in the tanks with a non-compressible material; 2) provide a barrier for inadvertent intrusion into the tank; 3) reduce contaminant mobility by a) limiting the hydraulic conductivity of the closed tank and b) reducing contact between the residual waste and infiltrating water; and 4) providing an alkaline, chemically reducing environment in the closed tank to control speciation and solubility of selected radionuclides.

The objective of this work was to identify a single (all-in-one) grout to stabilize and isolate the residual radionuclides in the tank, provide structural stability of the closed tank and serve as an inadvertent intruder barrier. This work was requested by V. A. Chander, High Level Waste (HLW) Tank Engineering, in HLW-TTR-2011-008. The complete task scope is provided in the Task Technical and QA Plan, SRNL-RP-2011-00587 Revision 0.

The specific objectives of this task were to:

1) Identify new admixtures and dosages for formulating a zero bleed flowable tank fill material selected by HLW Tank Closure Project personnel based on earlier tank fill studies performed in 2007.

The chemical admixtures used for adjusting the flow properties needed to be updated because the original admixture products are no longer available. Also, the sources of cement and fly ash have changed, and Portland cements currently available contain up to $5 \mathrm{wt}$. \% limestone (calcium carbonate).

2) Prepare and evaluate the placement, compressive strength, and thermal properties of the selected formulation with new admixture dosages.

3) Identify opportunities for improving the mix selected by HLW Closure Project personnel and prepare and evaluate two potentially improved zero bleed flowable fill design concepts; one based on the reactor fill grout and the other based on a shrinkage compensating flowable fill mix design.

4) Prepare samples for hydraulic property measurements for comparison to the values in the Fand H- Tank Farm Performance Assessments (PAs).

5) Identify a grout mix for the Tanks 18-F and 19-F Grout Procurement Specification [Forty, $2011 \mathrm{a}, \mathrm{b}, \mathrm{c}]$.

Results for two flowable zero bleed structural fill concepts containing 3/8 inch gravel (70070 Series and LP\#8 Series) and a sand only mix (SO Series) are provided in this report. Tank Farm Engineering and SRNL Project Management selected the 70070 mix as the base case for inclusion in Revision 0 of the Tanks 18-F and 19-F grout procurement specification [Forty $2011 \mathrm{a}$ ] and requested admixture recommendations and property confirmation for this formulation [Forty, $2011 \mathrm{~b}$ ]. Lower cementitious paste mixes were formulated because the $70070 \mathrm{mix}$ is over designed with respect to strength and generates more heat from hydration reactions than is desirable for mass pour application. Work was also initiated on a modification of the recommended mix which included shrinkage compensation to mitigate fast pathways caused by shrinkage cracking and poor physical bonding to the tank and ancillary equipment. Testing of this option was postponed to FY12. 
Mix, LP\#8-16 is recommended for inclusion in the specification for furnishing and delivering tank closure grout for Tanks 18-F and 19-F [Forty, $2011 \mathrm{c}$ ]. A shrinkage compensating variation of this mix, LP\#16C, has not been fully developed and characterized at this time. The mix design for LP\#816 is provided in the table below.

Tanks 18 and 19-F Bulk Fill Material Recommendation.

\begin{tabular}{|c|c|c|c|c|c|c|c|c|c|}
\hline $\begin{array}{c}\text { Mix } \\
\text { Number }\end{array}$ & $\begin{array}{c}\text { Cement } \\
\text { Type } \\
\text { I/II }\end{array}$ & $\begin{array}{c}\text { Slag } \\
\text { Grade } \\
100 \\
\end{array}$ & $\begin{array}{l}\text { Fly Ash } \\
\text { Class F }\end{array}$ & $\begin{array}{c}\text { Type G } \\
\text { Shrinkage } \\
\text { Compensating } \\
\text { Component }\end{array}$ & $\begin{array}{c}\text { Sand } \\
\text { Quartz }\end{array}$ & $\begin{array}{c}\text { Gravel } \\
\text { No. } 8 \\
3 / 8 \text { in. }\end{array}$ & Water & $\begin{array}{c}\text { HRWR } \\
\text { SIKA Visco } \\
\text { Crete } 2100\end{array}$ & $\begin{array}{c}\text { VMA } \\
\text { Diutan Gum } \\
\text { Kelco-Crete DG }\end{array}$ \\
\hline & \multicolumn{6}{|c|}{ Lbs/cyd } & Gal / cyd & Fl oz / cyd & g / cyd \\
\hline LP\#8-16 & 125 & 210 & 363 & 0 & 1790 & 800 & 48.5 & 41 & 200 \\
\hline
\end{tabular}




\section{TABLE OF CONTENTS}

APPROVALS.................................................................................

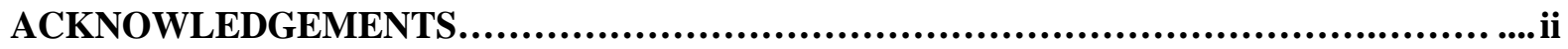

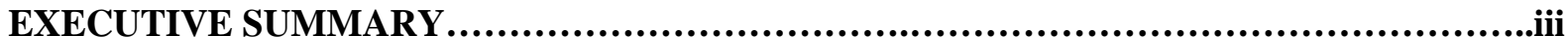

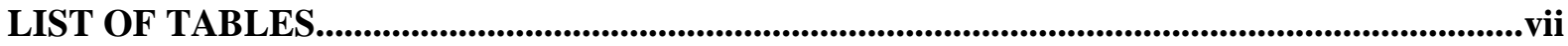

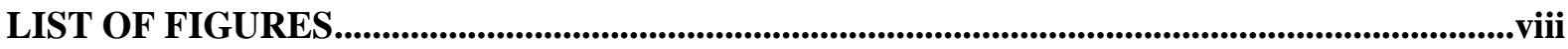

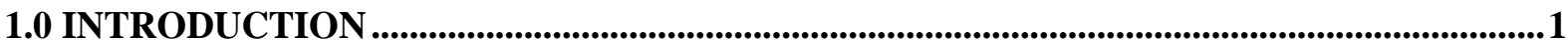

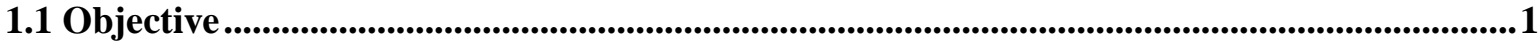

1.2 Background ................................................................................................................................................. 1

1.3 Previous SRS Tank Grout Mix Designs...........................................................................................2

1.4 Tank 18-F and 19-F Grout PA Attributes and General Requirements ....................................4

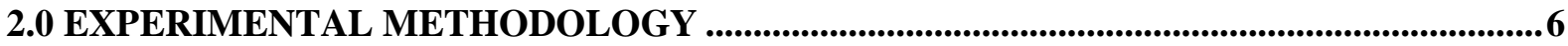

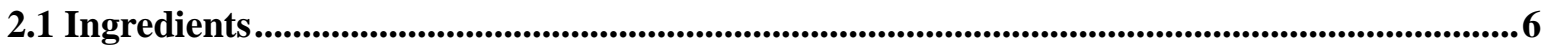

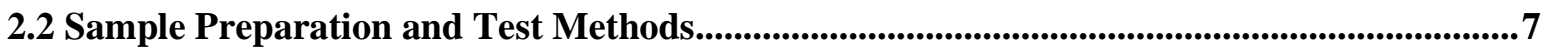

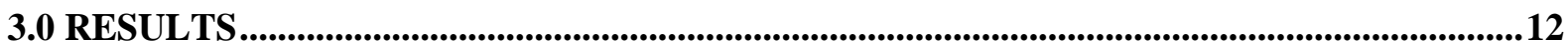

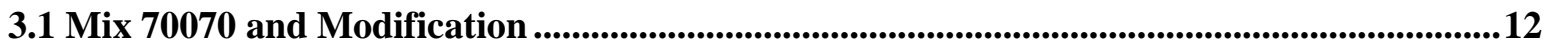

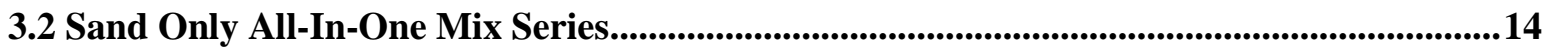

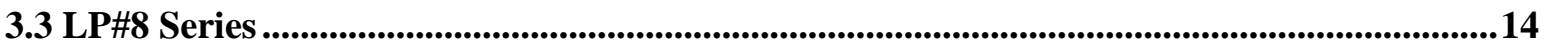

3.4 Thermal Property Characterization for Selected Mixes ..................................................17

3.5 Performance Assessment Hydraulic Property for Selected Mixes ......................................20

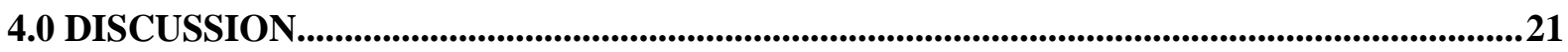

4.1 Compressive Strength....................................................................................................................21

4.2 Heat of Hydration ......................................................................................................................................22

4.3 Hydraulic Conductivity ...........................................................................................................23

5.0 CONCLUSIONS AND RECOMMENDATIONS .......................................................................24

6.0 FUTURE WORK ......................................................................................................................25

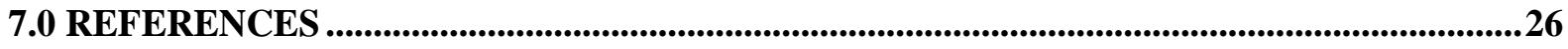

Attachment 1. MACTEC TEST REPORT ….........................................................................................28 


\section{LIST OF TABLES}

Table 1-1. SRS Tank Closure Grout Mix Designs from the 1990's [Langton, et. al, 2001]...........3

Table 1-2. Tank Closure Reducing Grout (Reducing Material Fill) Requirements [from Langton, et. al, 2007]......................................................................................5

Table 2-1. Ingredients Used to Prepare Samples of the FTF Closure Grouts. ...................................6

Table 2-2. Size Distribution of the Sand and No. 8 Stone [Waymer, 2011] ...................................7

Table 2-3. Test Methods Used to Determine Grout Properties.....................................................10

Table 3-1. Ingredients, Proportions and Properties for the FTF 70070 Series of Tank Fill

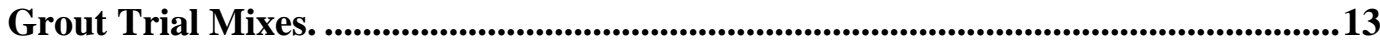

Table 3-2. Ingredients, Proportions and Properties for the Sand Only (SO) Series of Tank Fill Grout Trial Mixes.........................................................................................................15

Table 3-3. Ingredients, Proportions and Properties for Low Paste with No. 8 Stone (LP\#8) Series of Tank Fill Grout Trial Mixes.....................................................................16

Table 3-4. Summary of thermal properties for representative mixes.........................................19

Table 3-5. Hydraulic properties for the grouts recommended for closing Tanks 18-F and

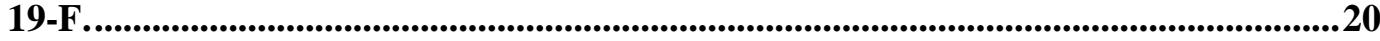

Table 3-6. Moisture retention as a function of applied pressure for LP\#8-016 and LP\#8-020. ..20

Table 4-1. Adiabatic Temperature Rise Data for Selected Candidate Tank Fill Grout Trial Mixes.

Table 4-2. Saturated Hydraulic Conductivities for Selected Candidate Tank Fill Grout Mixes.23

Table 5-1. Tanks 18 and 19-F Bulk Fill Material Recommendation. .24 


\section{LIST OF FIGURES}

Figure 1-1. General Layout of the SRS FTF. 2

Figure 2-1. Three cubic-foot concrete mixer used to prepare samples for grout formulation development..

Figure 2-2. (a) ASTM C-1611 Slump-Flow (25 inches) measurement and (b) Modified ASTM D-6103 8

Figure 2-3. Air content test apparatus and including unit weight bucket......................................8

Figure 2-4. Visual Examination: (a) no segregation (b) significant segregation..............................9

Figure 2-5. Hydraulic conductivity test apparatus and sample cells.............................................9

Figure 2-6. Pressure plate test configuration for moisture retention characterization.................10

Figure 2-7. Shrinkage measurement forms and instrumentation...................................................11

Figure 3-1. Adiabatic calorimeter data for Mixes FTF001H and FTF70070H............................18

Figure 3-2. Adiabatic calorimeter data for Mix LP\#8-021H.....................................................19

Figure 4-1. Compressive Strength versus cure time for LP\#8 Grout Series 2 mixes with different cement contents and water to cementitious material ratio of 0.580 .............21

Figure 4-2. Compressive Strength versus cure time for LP\#8 Grout Series 2 mixes with different cement contents and water to cementitious material ratio of 0.550 . 


\section{LIST OF ABBREVIATIONS}

$\begin{array}{ll}\text { ACI } & \text { American Concrete Institute } \\ \text { ASTM } & \text { American Society for Testing and Materials } \\ \text { CLSM } & \text { Controlled Low Strength Material } \\ \text { cm } & \text { centimeter } \\ \text { cyd } & \text { cubic yard } \\ \text { EDL } & \text { Engineering Development Laboratory } \\ \text { Eh } & \text { Oxidation - reduction potential (volts or milli volts) } \\ \text { FFA } & \text { Federal Facility Agreement } \\ \text { FTF } & \text { F-Area Tank Farm } \\ \text { GSA } & \text { General Separation Area } \\ \text { HRWR } & \text { High range water reducer } \\ \text { HTF } & \text { H-Area Tank Farm } \\ \text { K sat } & \text { Saturated hydraulic conductivity (for water at 20C) } \\ \text { lbs } & \text { pounds } \\ \text { PA } & \text { Performance Assessment } \\ \text { pH } & \text { Negative logarithm of the hydrogen ion activity in solution } \\ \text { psi } & \text { pounds per square inch } \\ \text { QA } & \text { Quality Assurance } \\ \text { SCMI } & \text { South Carolina Minerals Inc. } \\ \text { SRIP } & \text { Site Regulatory Integration and Planning } \\ \text { SRNL } & \text { Savannah River National Laboratory } \\ \text { SRNS } & \text { Savannah River Nuclear Solutions, LLC } \\ \text { SRR } & \text { Savannah River Remediation, LLC } \\ \text { SRS } & \text { Savannah River Site } \\ \text { STR } & \text { Subcontract Technical Representative } \\ \text { VMA } & \text { Viscosity Modifying Admixture } \\ & \end{array}$




\subsection{INTRODUCTION}

Cementitious grout will be used to close Tanks 18-F and 19-F. The functions of the grout are to: 1) physically stabilize the final landfill by filling the empty volume in the tanks with a non compressible material 2) provide a barrier for inadvertent intrusion into the tank, and 3) reduce contaminant mobility by a) limiting the hydraulic conductivity of the closed tank, b) reducing contact between the residual waste and infiltrating water, and 4) providing an alkaline, chemically reducing environment in the closed tank to control speciation and solubility of selected radionuclides.

\subsection{Objective}

The objective of this work was to identify a single (all-in-one) grout to stabilize and isolate the residual radionuclides in the tank, provide structural stability of the closed tank and serve as an inadvertent intruder barrier. This work was requested by V. A. Chander, High Level Waste (HLW) Engineering, in HLWTTR-2011-008 [Chander, 2011]. The complete task scope is provided in the Task Technical and QA Plan, SRNL-RP-2011-00587 Rev. 0 [Stefanko, et al., 2011].

The specific objectives of this task were to:

1) Identify new admixtures and dosages for formulating a zero bleed flowable tank fill material selected by HLW Tank Closure Project personnel based on tank fill studies performed in 2007.

The chemical admixtures used for adjusting the flow properties needed to be updated because the original admixture products are no longer available. Also, the sources of cement and fly ash have changed, and Portland cements currently available contain up to 5 wt. \% limestone (calcium carbonate).

2) Prepare and evaluate the placement, compressive strength, and thermal properties of the selected formulation with new admixture dosages.

3) Identify opportunities for improving the mix selected by HLW Closure Project personnel and prepare and evaluate two potentially improved zero bleed flowable fill design concepts; one based on the reactor fill grout and the other based on a shrinkage compensating flowable fill mix design.

4) Prepare samples for hydraulic property measurements for comparison to the values in the F- and HTank Farm Performance Assessments (PAs).

5) Identify a structural flowable fill mix design for the Tanks 18-F and 19-F Grout Procurement Specification [Forty 2011, a, b, c].

\subsection{Background}

The FTF is located in the General Separations Area (GSA) of the Savannah River Site (SRS). The FTF includes twenty-two waste tanks constructed between 1951 and 1976. See Figure 1-1. In contrast to Tanks 17F and 20F, which were closed in 1997, Tank 18-F and 19-F will be filled with one grout formulation, a structural flowable fill which is chemically reducing, i.e., an All-In-One mix design [SRR Closure Module, 2011].

Waste removal operations are currently in progress in F Tank Farm to support closure of the noncompliant tanks in accordance with the Federal Facility Agreement (FFA) closure schedule. Heel removal and characterization in Tanks 18-F and 19-F are complete. 
SRNL-STI-2011-00551

Revision 1

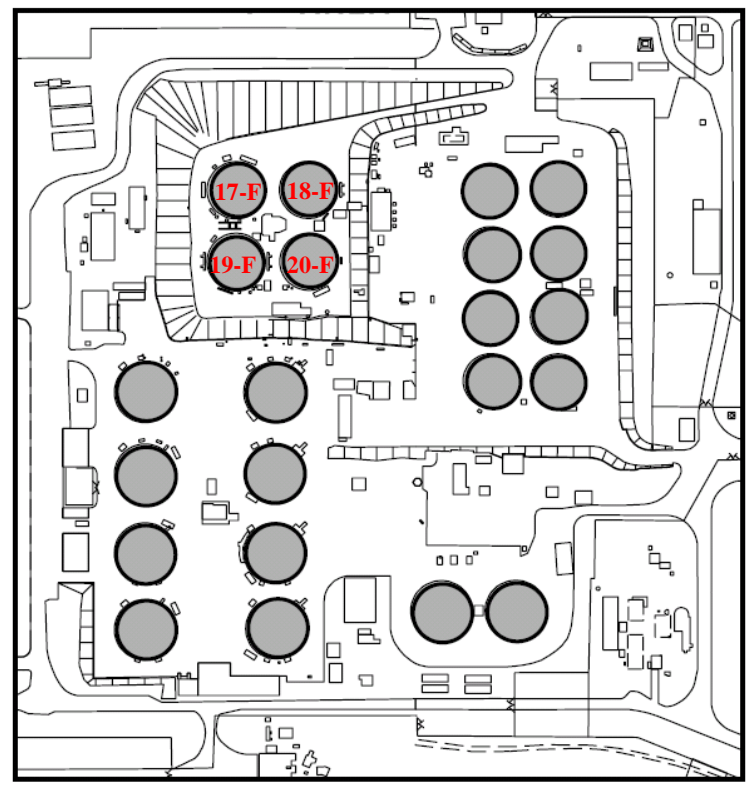

Figure 1-1. General Layout of the SRS FTF.

\subsection{Previous SRS Tank Grout Mix Designs}

In 1997, two single-shell carbon steel tanks (17-F and 20-F) in the FTF were emptied and filled with grout. Both tanks had a capacity of 1.3 million gallons and were originally used to store low-heat waste. The original concept was to use three different grouts in the closure concept: a high strength reducing grout to encapsulate the residual waste, a Controlled Low-Strength Material (CLSM) ${ }^{1}$ for filling the bulk of the tank and, a 2000 psi grout as an intruder barrier in the top of the tank.

The high strength reducing grout was designed by engineers at the Construction Technology Laboratory, Skokie, IL. SRNL modified the original SRS CLSM and 2000 psi grout mixes to eliminate bleed water. ${ }^{2}$ Initial testing of the Site CLSM and 2000 psi grout indicated that a significant amount of bleed water would be generated in the closed tanks. Ingredients in the grout mixes used to fill these tanks are listed in Table 1-1 [Langton, et. al, 2001].

In 1998, research was conducted to develop an all-in-one HLW tank fill grout that could be used for both encapsulating the residual waste and bulk fill [Langton and Rajendran, 1998]. The driver for this work was the desire to simplify the production requirements for tank fill material. This work resulted in an allin-one zero bleed reducing fill/grout mix which is also provided in Table 1-1. This mix was adopted for the Reducing CLSM, Mix No OPCEXE-X-P-0-BS, listed in the current SRS Specification C-SPP-F00047, Revision 2 [C-SPP-F-00047, Revision 2, 2003].

\footnotetext{
${ }^{1}$ CLSM is a cementitious flowable fill that is used as backfill or infill and has soil-like properties. It is self compacting and consequently does not required mechanical compaction to achieve design density. CLSM typically contains sand, fly ash and less than 100 pounds of hydraulic material per cubic yard of fill.

Hydraulic cementitious material reacts with water to form insoluble hydrated compounds. Portland cement is the best known hydraulic cement. Slag cement is also hydraulic once it has been activated.

${ }^{2}$ Eliminating bleed water resulted in eliminating the need for removing and disposing of radioactively contaminated liquid from the tanks. It also reduced settling and stratification which resulted in improved cured properties. Bleed water is not a problem when these materials are used in conventional soil backfill applications where the water can drain off or evaporate.
} 
Table 1-1. SRS Tank Closure Grout Mix Designs from the 1990’s [Langton, et. al, 2001].

\begin{tabular}{|c|c|c|c|c|c|}
\hline & \multicolumn{3}{|c|}{$\begin{array}{c}\text { Tanks } 17-\mathrm{F} \text { and } 20-\mathrm{F} \\
1997\end{array}$} & \multirow{2}{*}{$\begin{array}{c}1998 \text { All-In-One } \\
\text { (modification of } \\
\text { 1997 flowable fill) } \\
\text { SRS All-In One } \\
\text { Zero Bleed } \\
\text { Reducing } \\
\text { Fill/Grout** } \\
\text { OPCEXE-X-P-0-BS } \\
\end{array}$} & \multirow{2}{*}{$\begin{array}{c}2007 \\
\text { Alternative } \\
\text { All-In-One Study } \\
\\
\text { All-In-One } \\
\text { Mix 070070 } \\
\text { [Langton, et. al, 2007] } \\
\end{array}$} \\
\hline Ingredients & $\begin{array}{c}\text { SRS } \\
\text { Reducing } \\
\text { Grout } \\
\end{array}$ & $\begin{array}{l}\text { SRS Zero- } \\
\text { Bleed } \\
\text { Flowable } \\
\text { Fill } \\
\end{array}$ & $\begin{array}{l}\text { SRS Zero- } \\
\text { Bleed } \\
2000 \text { psi } \\
\text { Grout } \\
\end{array}$ & & \\
\hline $\begin{array}{l}\text { Portland Cement } \\
\text { Type I/II } \\
\text { (lbs / cu yd) }\end{array}$ & 1353 & 150 & 550 & 75 & 185 \\
\hline $\begin{array}{l}\text { Slag Grade } 100 \\
\text { (lbs / cu yd) }\end{array}$ & 209 & --- & --- & 210 & 260 \\
\hline $\begin{array}{l}\text { Fly Ash, Class F } \\
\text { (lbs / cu yd) }\end{array}$ & --- & 500 & --- & 375 & 850 \\
\hline $\begin{array}{l}\text { Silica Fume } \\
\text { (lbs / cu yd) }\end{array}$ & 90 & --- & --- & --- & --- \\
\hline $\begin{array}{l}\text { Quartz Sand } \\
\text { ASTM C-33 } \\
\text { (lbs / cu yd) }\end{array}$ & $\begin{array}{c}1625 \\
\text { (masonry } \\
\text { sand) }\end{array}$ & $\begin{array}{c}2300 \\
\text { (concrete } \\
\text { sand) }\end{array}$ & $\begin{array}{c}2285 \\
\text { (concrete } \\
\text { sand) }\end{array}$ & $\begin{array}{c}2300 \\
\text { (concrete sand) }\end{array}$ & 942 \\
\hline $\begin{array}{l}\text { ASTM C-33 } \\
\text { No. } 8 \text { Stone } \\
\text { 3/8 inch Crushed } \\
\text { Granite (lbs/cu yd) }\end{array}$ & --- & --- & --- & --- & 946 \\
\hline $\begin{array}{l}\text { Water } \\
\text { (gallons /cu yd) } \\
\text { (lbs/cu yd) }\end{array}$ & $\begin{array}{l}86.4 \\
(721)\end{array}$ & $\begin{array}{c}63 \\
(526)\end{array}$ & $\begin{array}{c}65 \\
(542)\end{array}$ & $\begin{array}{c}60 \\
(500)\end{array}$ & $\begin{array}{c}61 \\
(506)\end{array}$ \\
\hline $\begin{array}{l}\text { HRWR } \\
\text { (fl oz. / cu yd) }\end{array}$ & 250 & $\begin{array}{c}90 * \\
\text { Adva Flow }\end{array}$ & $\begin{array}{c}140 \\
\text { Adva Flow }\end{array}$ & $\begin{array}{c}90 * \\
\text { Adva Flow }\end{array}$ & $\begin{array}{c}54 \\
\text { Adva Flex }\end{array}$ \\
\hline $\begin{array}{l}\text { Viscosifier Kelco- } \\
\text { crete }^{\circledR} \\
\text { (grams / cu yd)** }^{* *}\end{array}$ & --- & 275 & 275 & 275 & 216 \\
\hline $\begin{array}{l}\text { Set Retarder } \\
\text { (Hydration } \\
\text { Stabilizer } \\
\text { (fl oz. / cu yd) }\end{array}$ & 150 & --- & --- & --- & $\begin{array}{c}\text { Up to } 4 \\
\text { Recover } \\
\text { As required }\end{array}$ \\
\hline $\begin{array}{l}\text { Sodium } \\
\text { Thiosulfate } \\
\text { (lbs / cu yd) }\end{array}$ & 2.1 & --- & --- & 2.1 (optional) & 2.1 (optional) \\
\hline
\end{tabular}

* Advaflow and Kelco-crete ${ }^{\circledR}$ were premixed prior to incorporation in the zero-bleed mixes rather than adding as individual components.

** This mix was adopted for the Reducing CLSM, Mix No OPCEXE-X-P-0-BS, listed in the SRS Concrete Specification.

In 2006 and 2007 samples of Mix No OPCEXE-X-P-0-BS were prepared and characterized along with several alternative all-in-one mix designs in anticipation of closing Tanks 18-F and 19-F. The results of 
this work are presented elsewhere [Langton, 2007]. In 2010, one of the alternative grout mixes, Mix No. 070070, was selected by F-Tank Farm Engineering and Closure Project personnel for consideration as the Tank 18-F and 19-F closure grout and for inclusion in revision 0 of the procurement specification for the tank fill grout [Forty, et al., 2011 a].

During 2009 and 2010, flowable structural fill grouts were designed for closing SRS P- and R-Reactor facilities. These mixes were designed to be robust and suitable for high volume placements.

Approximately 180,000 cubic yards of flowable structural fill were placed in the below grade portions of the 105 P- and R- Reactor facilities.

This report presents data for Mix No. 70070 per request of F-Tank Farm Engineering in addition to data for developing improved mix designs for closing Tanks $18-\mathrm{F}$ and $19-\mathrm{F}$. These new grout designs are also all-in-one mixes (compared to the original three layer concept used in Tanks 17-Fand 20-F). These new grouts were designed to address marginal performance of the Mix No. 70070 mix (high reaction heat) and the original sand only all-in-one grout (<2000 psi after 28 days), respectively. The new grouts combine features of the flowable zero bleed structural fill mix was used in the successful SRS reactor closure projects with chemical features (stabilizing grout) and strength requirements (capping grout) of an all-inone tank closure grout.

\subsection{Tank 18-F and 19-F Grout PA Attributes and General Requirements}

The important attributes of the cured tank fill materials, with respect to properties that control leaching (permeability and chemistry), are listed below in a general order of priority:

A. Low water infiltration (conductivity) through the in-place grout, over the long term

B. High reducing capacity, over the long term

C. High long term strength of in-place grout

D. Low long term cracking

E. Low long term degradation of the in-place grout

F. Adequate flowability of the grout during placement.

These attributes for tank closure grouts were combined with and interpreted in terms of engineering properties to derive general engineering parameters. See Table 1-2. The link between the general parameters and the detailed requirements is provided in a separate report [Stefanko and Langton, 2011].

Requirements for fresh slurry properties and cured properties are listed along with the basis for each requirement. Test methods for determine parameter values are also provided. Properties which are required for the F-Tank Farm (FTF) Performance Assessment (PA) are identified.

A short list of current tank closure all-in-one reducing grout requirements was provided by Savannah River Remediation (SRR) F-Tank Farm Engineering in the Technical Task Request (TTR) that controls this work [Chander, 2011]. These requirements were used as criteria for evaluating candidate grout formulations and for designing improved formulations. The expanded list of requirements for tank closure grout is provided in SRNL-RP-2011-00977 and includes: 1) modifications to the short list, 2) the bases for the requirements, and 3) explanation of the requirements and tests needed to support the FTF PA [Stefanko and Langton, 2011]. 
Table 1-2. Link Between Historic Tank Closure Reducing Grout Attributes, Physical Properties, and Engineering Parameters [from Langton, et. al, 2007].

\begin{tabular}{|c|c|c|}
\hline SRIP Attributes [Newman, 2006] & Physical Property & Engineering Parameter \\
\hline $\begin{array}{l}\text { Low water infiltration (conductivity) } \\
\text { through the in-place grout, over the long } \\
\text { term }\end{array}$ & Saturated Permeability less than current tank fill grout & $\begin{array}{l}\text { 1. Saturated Permeability } \\
\mathrm{K}_{\mathrm{sat}} \leq 2 \mathrm{E}-08 \mathrm{~cm} / \mathrm{sec} \\
\text { 2. Durable }\end{array}$ \\
\hline High reducing capacity, over the long term & $\begin{array}{l}\text { High long-term negative Eh. Current approach is to use the same } \\
\text { amount of slag cement as used in earlier grout mix designs }\end{array}$ & $\begin{array}{l}\text { At least } 210 \text { lbs of slag per cubic yard of } \\
\text { reducing grout }\end{array}$ \\
\hline High long-term strength of in-place grout & $\begin{array}{l}\text { High long-term strength at any time is not required. The PA identifies a } \\
2000 \text { psi intruder barrier. This is also the minimum strength required for } \\
\text { low permeability reducing grout. }\end{array}$ & $\begin{array}{l}\text { At least } 2500 \text { psi at } 90 \text { days to meet } 2000 \text { psi } \\
\text { req. for strong grout }\end{array}$ \\
\hline Low long-term cracking & $\begin{array}{l}\text { Minimize the potential for cracking: } \\
\text { 1. Negligible early stage shrinkage } \\
\text { 2. Negligible chemical incompatibility of materials } \\
\text { 3. Negligible susceptibility to environmental corrodents } \\
\text { 4. No cracking as the result of overburden loading } \\
\text { 5. Seismic loading not considered }\end{array}$ & $\begin{array}{l}\text { 1. Use as much dimensionally stable sand and } \\
\text { gravel as possible } \\
\text { 2. Cracking mechanisms due to material } \\
\text { incompatibility, phase changes, and corrodents } \\
\text { were addressed elsewhere [Langton, 2007]. } \\
\text { Continue with same materials unless new testing } \\
\text { and research indicate potential for expansion. } \\
\text { 3. Overburden loading is not an issue. }\end{array}$ \\
\hline $\begin{array}{l}\text { Low long-term degradation of the in-place } \\
\text { grout }\end{array}$ & $\begin{array}{l}\text { Durable: Perform design function over } 100 \text { s to } 1000 \text { s of years } \\
\text { 1. Negligible cracking due to internal expansive reactions and external } \\
\text { forces } \\
\text { 2. Maintain chemical alkalinity and reducing chemistry }\end{array}$ & $\begin{array}{l}\text { 1. Chemical degradation is addressed elsewhere } \\
\text { [Langton, 2007]. } \\
\text { 2. Use equivalent or more portland cement }(\mathrm{pH}) \\
\text { and slag cement (Eh). Continue with same } \\
\text { materials. }\end{array}$ \\
\hline $\begin{array}{l}\text { Adequate flowability of the grout during } \\
\text { placement }\end{array}$ & $\begin{array}{l}\text { Flow } 35 \text { feet in a tank with a } 70 \text { feet diameter from a central discharge } \\
\text { point from a 2-10 foot free drop }\end{array}$ & $\begin{array}{l}\text { Grout flow }>11 \text { inches per ASTM D } 6103 \\
\text { Slump flow }>25 \text { inches ASTM C } 1611\end{array}$ \\
\hline \multicolumn{3}{|l|}{ Other Considerations } \\
\hline Production & $\begin{array}{l}\text { 1. Suitable for on-site continuous or central mixer batch plant using } \\
\text { locally available aggregate and simplify admixture additions if possible } \\
\text { 2. Production Rate of at least } 600 \text { cubic yards/day } \\
\text { 3. Pumpable } 1500 \text { feet }\end{array}$ & $\begin{array}{l}\text { HRWR and VMA compatibility to enable } \\
\text { addition as a slurry to support auger mixing. }\end{array}$ \\
\hline Fresh Properties & $\begin{array}{l}\text { 1. High flow (grout) for slump-flow ( } 3 / 8 \text { inch aggregate) } \\
\text { 2. Set time }<24 \text { hours } \\
\text { 3. Minimal bleed water (no bleed water is desirable) and segregation } \\
\text { 4. Air entrainment not required for below grade placement } \\
\text { 5. Cure under moist conditions } \\
\text { 6. Low shrinkage }\end{array}$ & $\begin{array}{l}\text { 1. Slump-flow }>25 \text { inches, grout flow } 11-15 \text { in. } \\
\text { 2. Set time }<24 \text { hours } \\
\text { 3. Zero bleed after } 24 \text { hours } \\
\text { 4. No air entrainment } \\
\text { 5. High unit weight, low air content } \\
\text { 6. Low paste content, moist cure, zero bleed }\end{array}$ \\
\hline Cured Properties & $\begin{array}{l}\text { 1. } 90 \text { day strength } \geq 2000 \mathrm{psi} \\
\text { 2. Permeability }<2 \mathrm{E}-08 \mathrm{~cm} / \mathrm{sec} \text { (strong grout measurements) } \\
\text { 3. Low Shrinkage } \\
\text { 4. Heat of hydration suitable for mass pours }\end{array}$ & $\begin{array}{l}\text { 1. } 90 \text { day strength } \geq 2000 \mathrm{psi} \\
\text { 2. Permeability }<2 \mathrm{E}-08 \mathrm{~cm} / \mathrm{sec} \text { (strong grout } \\
\text { measurements } \\
\text { 3. Portland cement }+ \text { slag cement less than } \\
\text { about } 450 \mathrm{lbs} / \text { cubic yard. }\end{array}$ \\
\hline
\end{tabular}


SRNL-STI-2011-00551

Revision 1

\subsection{EXPERIMENTAL METHODOLOGY}

\subsection{Ingredients}

Grout mixes tested in this study were prepared with bulk materials obtained from local suppliers and chemical admixtures that are distributed nationwide. The Type I/II cement was manufactured by LaFarge, Inc. at their cement plant in Harleyville, SC. The Grade 100 slag cement was manufactured by Holcim, Inc., Birmingham, AL, and the fly ash was obtained from the Wateree Power Plant and supplied by SEFA, Inc. SRS process water was used as the mixing water. The ingredients are listed in Table 2-1. The aggregate properties are listed in Table 2-2.

Table 2-1. Ingredients Used to Prepare Samples of the FTF Closure Grouts.

\begin{tabular}{|c|c|c|c|}
\hline Material & Specification & Supplier / Address & Phone Number \\
\hline $\begin{array}{l}\text { Portland cement } \\
\text { (Type I/II) }\end{array}$ & ASTM C150 & $\begin{array}{l}\text { LaFarge, Cement } \\
\text { Harleyville, SC obtained } \\
\text { from Lafarge Ready Mix } \\
\text { Augusta, GA }\end{array}$ & 706-823-4471 \\
\hline $\begin{array}{l}\text { Slag cement } \\
\text { (Grade 100) }\end{array}$ & ASTM C987 & $\begin{array}{l}\text { Holcim, Inc. } \\
3235 \text { Satellite Blvd. } \\
\text { Duluth, GA } 30096\end{array}$ & $800-292-4355$ \\
\hline $\begin{array}{l}\text { Fly ash } \\
\text { (Class F) }\end{array}$ & ASTM C618 & $\begin{array}{l}\text { Wateree Power Plant,* } \\
\text { SC } \\
\text { SEFA, Inc. }\end{array}$ & $800-241-4943$ \\
\hline Concrete sand & ASTM C33 & $\begin{array}{l}\text { SCMI } \\
\text { Clearwater SC } \\
\text { obtained from Lafarge } \\
\text { Ready Mix, Jackson, SC }\end{array}$ & 706-823-4471 \\
\hline $\begin{array}{l}\text { No. } 8 \text { stone } \\
3 / 8 \text { inch gravel (granite) }\end{array}$ & ASTM C33 & $\begin{array}{l}\text { Martin Marietta Quarry } \\
\text { Augusta, GA } \\
\text { obtained from Lafarge } \\
\text { Ready Mix, Jackson, } \\
\text { SC }\end{array}$ & 706-541-0187 \\
\hline \multicolumn{4}{|l|}{ HRWR } \\
\hline Sika ViscoCrete 2100 & $\begin{array}{l}\text { ASTM C494 } \\
\text { Type F } \\
\end{array}$ & Sika Corporation & 717-821-3721 \\
\hline \multicolumn{4}{|l|}{ Hydration Stabilizer** } \\
\hline Recover & $\begin{array}{l}\text { ASTM C494 } \\
\text { Type B }\end{array}$ & $\begin{array}{l}\text { W.R. Grace \& Co. } \\
62 \text { Whittemore Ave. } \\
\text { Cambridge, MA } 02140\end{array}$ & $617-876-1400$ \\
\hline \multicolumn{4}{|l|}{ Viscosifier } \\
\hline $\begin{array}{l}\text { Kelco-Crete D } \\
\text { (Diutan Gum) }\end{array}$ & & $\begin{array}{l}\text { CP Kelco, Inc. } \\
\text { 8355 Aero Dr. } \\
\text { San Diego, CA } 92123\end{array}$ & $858-292-4900$ \\
\hline SRS domestic water & & SRS & \\
\hline
\end{tabular}


Table 2-2. Size Distribution of the Sand and No. 8 Stone [Waymer, 2011].

\begin{tabular}{|c|c|c|c|c|}
\hline Property & \multicolumn{2}{|c|}{ Concrete Sand } & \multicolumn{2}{|c|}{ No. 8 Aggregate (3/8 inch) } \\
\hline Bulk Unit Weight $\left(\mathrm{lb} / \mathrm{ft}^{3}\right)$ & \multicolumn{2}{|c|}{85 @ 1.6 wt. \% SSD* } & \multicolumn{2}{|c|}{$93 @ 0.6$ wt. \% SSD* } \\
\hline Specific Gravity (particle) & \multicolumn{2}{|c|}{2.65} & \multicolumn{2}{|c|}{2.56} \\
\hline Composition & \multicolumn{2}{|c|}{ Quartz } & \multicolumn{2}{|c|}{ Granite } \\
\hline Moisture Content (as received)* & \multicolumn{2}{|c|}{$0.7-6.5$ wt. $\%$} & \multicolumn{2}{|c|}{$\sim 0$} \\
\hline Particle size Distribution $^{+}$ & $\begin{array}{l}\text { Wt. \% } \\
\text { Passing }\end{array}$ & $\begin{array}{l}\text { Cum. Wt. \% } \\
\text { Retained }\end{array}$ & $\begin{array}{l}\text { Wt. \% } \\
\text { Passing }\end{array}$ & $\begin{array}{l}\text { Cum. Wt. \% } \\
\text { Retained }\end{array}$ \\
\hline $1 / 2$ inch $(12.5 \mathrm{~mm})$ & 100 & 0 & 99.4 & 0.6 \\
\hline $3 / 8$ inch sieve & 100 & 0 & 91.8 & 8.2 \\
\hline $1 / 4$ inch sieve & -- & -- & 40.0 & 60.0 \\
\hline \#4 sieve $(4.75 \mathrm{~mm})$ & 99 & 1 & 14.2 & 85.8 \\
\hline \#5 sieve $(4.00 \mathrm{~mm})$ & -- & -- & 6.3 & 93.7 \\
\hline \#8 sieve (2.36 mm) & 96 & 4 & 0.6 & 99.4 \\
\hline \#16 sieve $(1.18 \mathrm{~mm})$ & 81 & 19 & -- & -- \\
\hline \#30 sieve $(600 \mu \mathrm{m})$ & 50 & 50 & -- & -- \\
\hline$\# 50$ sieve $(300 \mu \mathrm{m})$ & 17 & 83 & -- & -- \\
\hline$\# 100$ sieve $(150 \mu \mathrm{m})$ & 2 & 98 & -- & -- \\
\hline Fineness Modulus & -- & 2.6 & -- & -- \\
\hline
\end{tabular}

* Moisture content varied as a function of the storage time and conditions as determined by URS Quality and Testing Division personnel. ASTM C128 and ASTM C566 (total moisture). SSD = Surface Saturated Dry.

${ }^{+}$Percentage passing through each sieve as determined by ASTM C136.

\subsection{Sample Preparation and Test Methods}

Sample preparation and most testing were performed in the SRS Civil Engineering Test Laboratory which is operated by URS, Quality and Testing Division. The laboratory is located in N-Area. Samples were prepared according to ASTM C192 and cured in a constant temperature $\left(73^{\circ} \mathrm{F} \pm 2^{\circ} \mathrm{F}\right)$ curing room at $100 \%$ relative humidity. A three cubic foot concrete mixer was used to prepare the grout mixes. See Figure 2-1. The batch size was typically 0.75 to 1.0 cubic feet.

The order of addition of ingredient to the mixer was as follows: gravel, sand, a portion of the water, fly ash, slag, cement and admixtures. The remainder of the water was added in total or in parts during the addition of the fly ash, slag, and cement. The mixing time was approximately five minutes after all of the ingredients were added. A sample was collected for the slump-flow measurement (Method ASTM C1161). After the test was completed, the material was returned to the mixer and mixed for another 5 minutes and additional HRWR or VAM was added if necessary. The batch was allowed to rest for another 5 minutes prior to measuring fresh properties. After the final slump-flow was measured, (See Figure 2-2a) the remaining material was used for unit weight, air content (See Figure 2-3), set time, and bleed water determinations; evaluation of flow under static conditions (modified ASTM D6103, Figure 2-2b); and to cast samples for strength, permeability and other hydraulic property measurements.

Three by six inch cylinders were cast for compressive strength measurements as a function of curing times (7, 28, and 90 days), and moisture retention characterization, i.e, volumetric water content as a function of head pressure (pressure plate test). Two by four inch samples were cast for hydraulic conductivity measurements at the URS laboratory (Method ASTM D5084 Method C). Three by six inch cylinders were cast for hydraulic conductivity measurements of selected samples performed at MACTEC (Method ASTM D5084 Method F). 


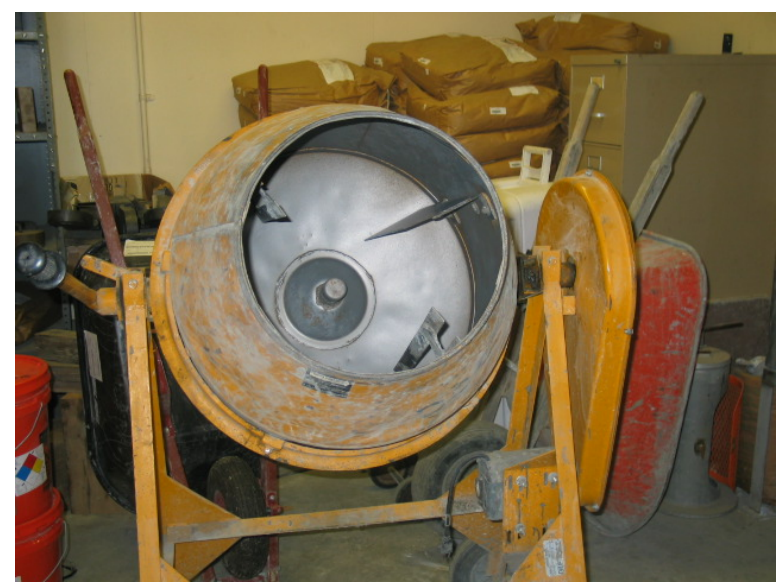

Figure 2-1. Three cubic-foot concrete mixer used to prepare samples for grout formulation development.

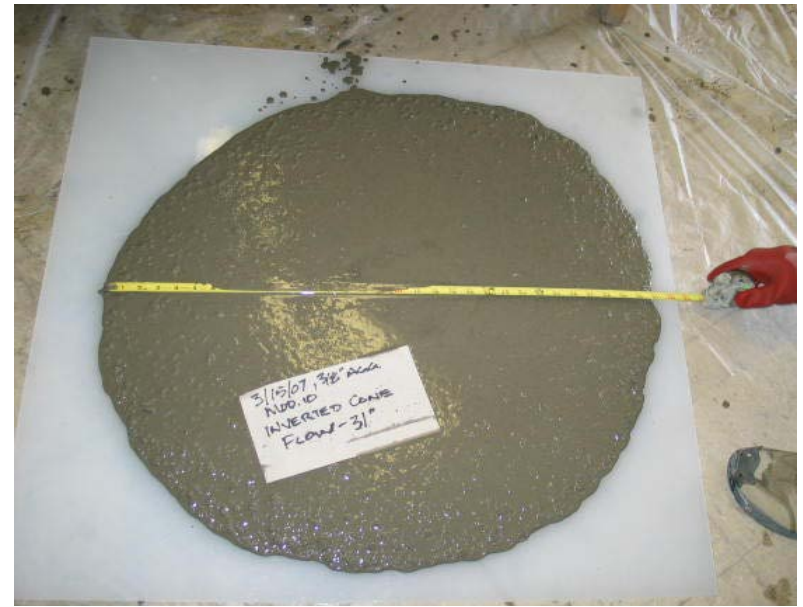

(a)

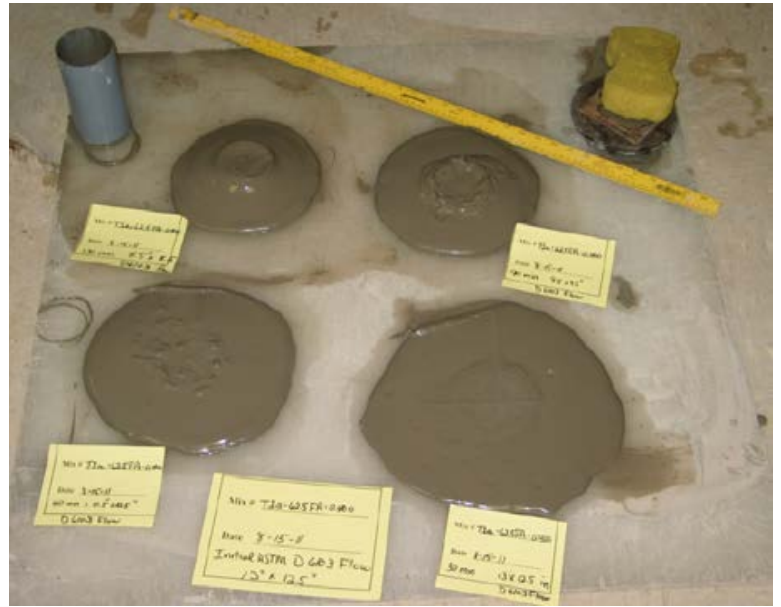

(b)

Figure 2-2. (a) ASTM C1611 Slump-Flow (25 inches) measurement and (b) Modified ASTM D6103 Flow under static conditions determination (12.5 inches for initial reading).

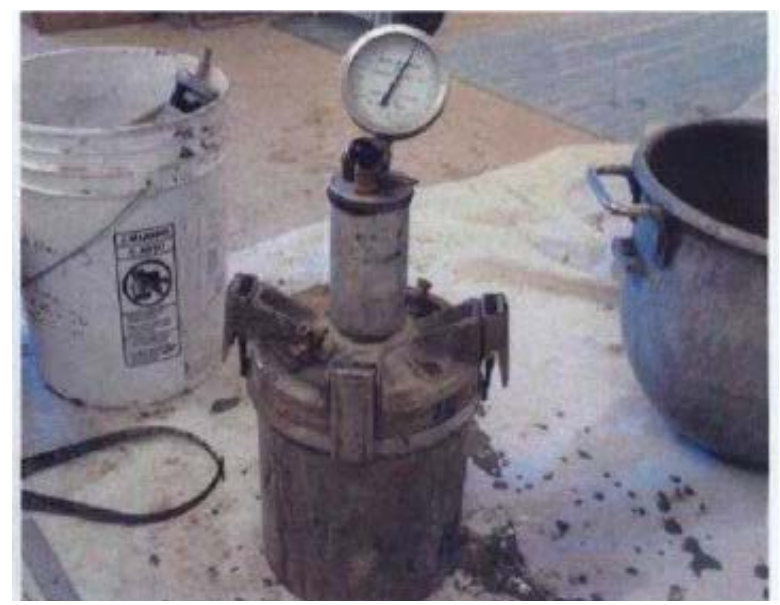

Figure 2-3. Air content test apparatus and including unit weight bucket. 


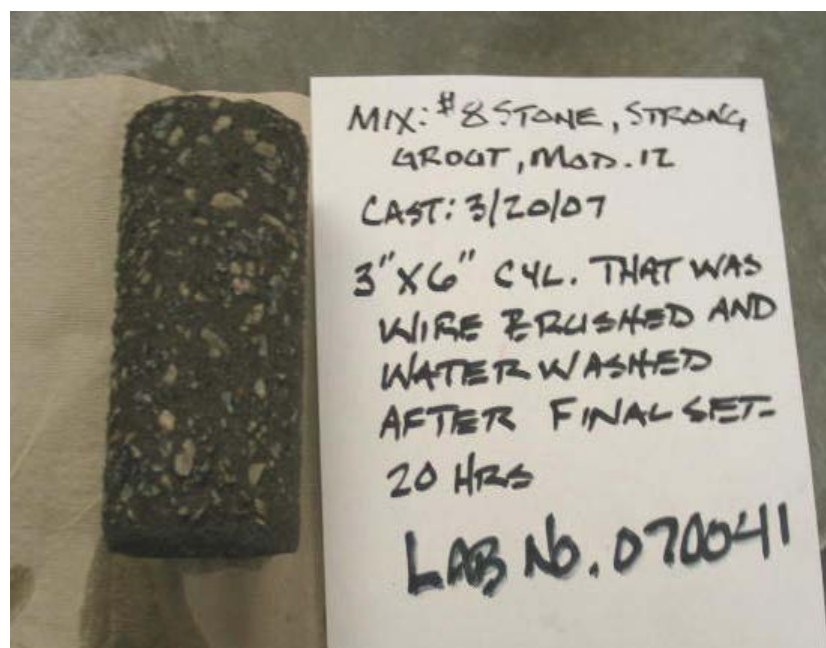

(a)

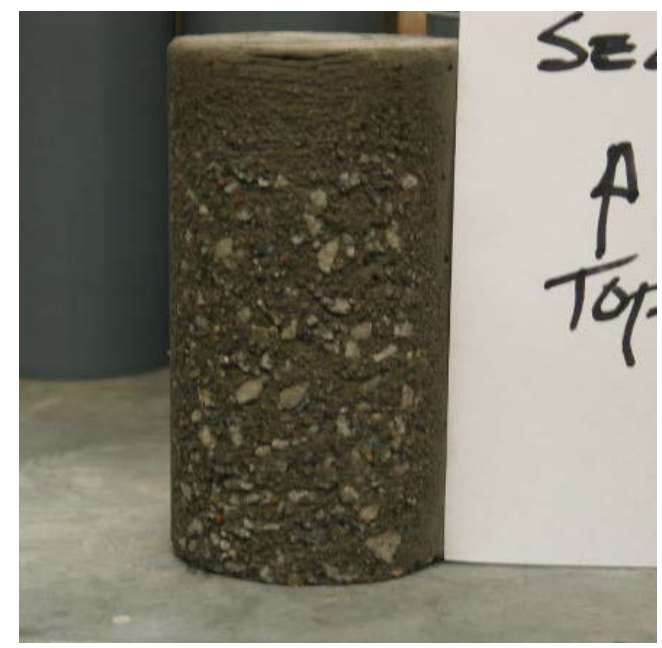

(b)

Figure 2-4. Visual Examination: (a) no segregation (b) significant segregation.

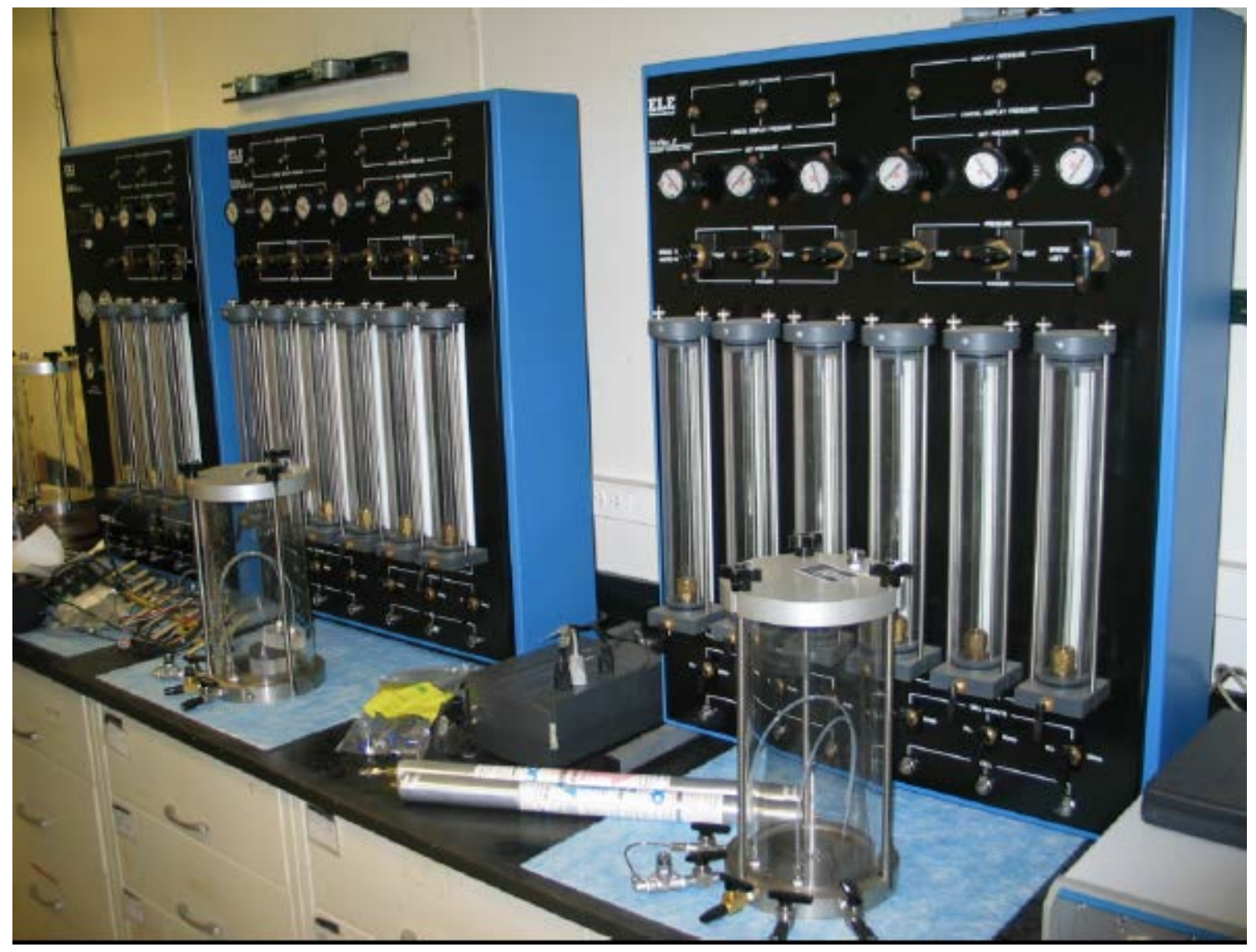

Figure 2-5. Hydraulic conductivity test apparatus and sample cells. 


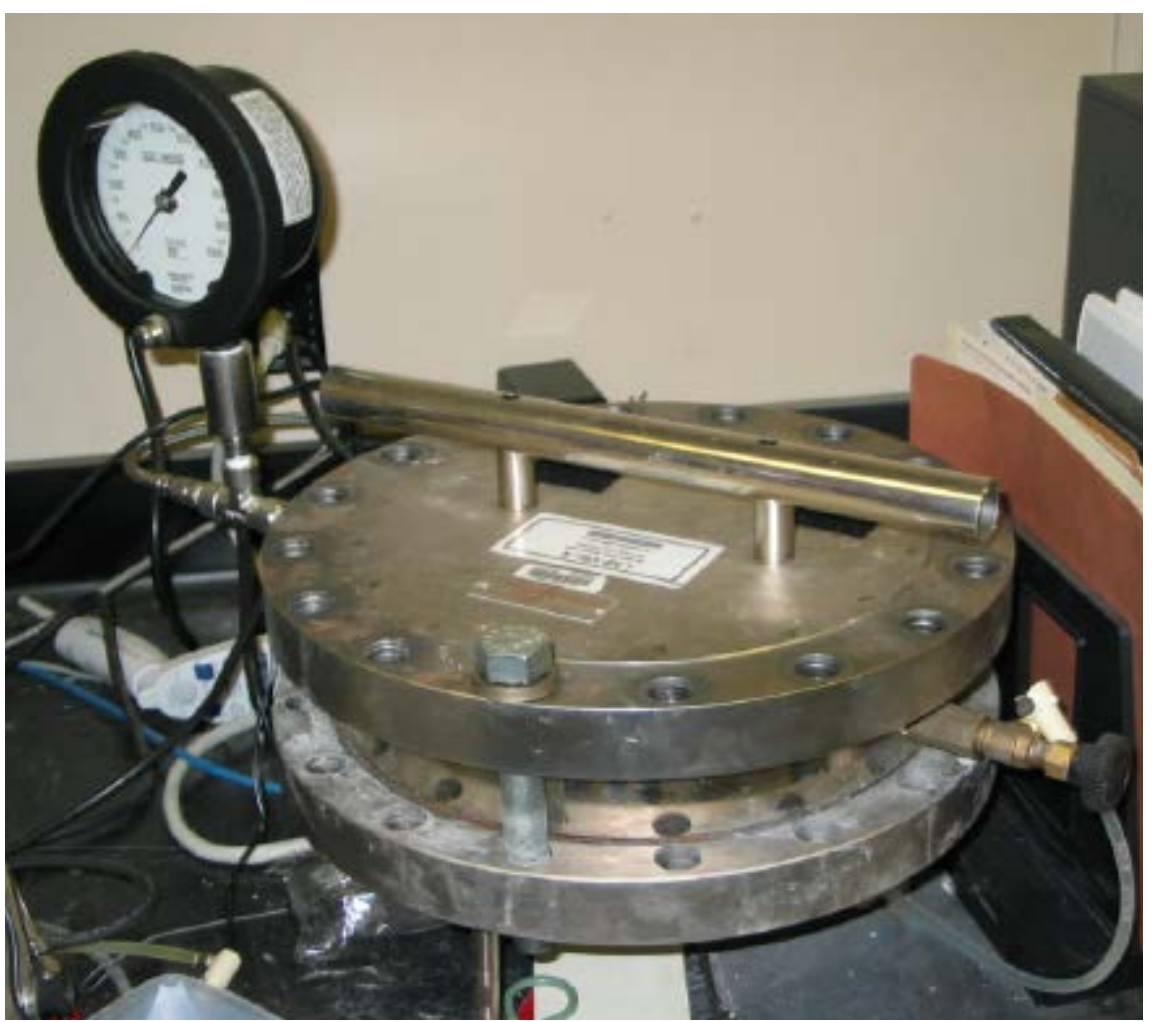

Figure 2-6. Pressure plate test configuration for moisture retention characterization.

Test methods used for evaluating mix designs are listed in Table 2-3. A comprehensive list of the test methods used to characterize the recommended formulations including the test methods for measuring the hydraulic properties for the FTF PA are provide in a separate report [Stefanko and Langton, 2011].

Table 2-3. Test Methods Used to Determine Grout Properties.

\begin{tabular}{|l|c|}
\hline Properties & ASTM Methods \\
\hline Fresh Properties & D6103 \\
\hline Flow (Initial and Static Flow) & C1611 \\
\hline Slump Flow & UPV and visual \\
\hline Set Time & C232 \\
\hline Bleed Water (24 hr.) & Visual \\
\hline Segregation* & C138 \\
\hline Unit Weight & C231 \\
\hline Air Content & C39 \\
\hline Cured Properties & D5084 Methods C and F \\
\hline Compressive Strength & SRNL Adiabatic Calorimeter \\
\hline Saturated Hydraulic Conductivity & Seat of Hydration \\
\hline Heat
\end{tabular}

* Segregation was measured by visual examination of a washed "green sample. See Figure 2-4. ASTM C1621 includes a method for quantifying segregation. The necessary test equipment has been acquired and will be used for future testing. 
Special test forms were designed and instrumented to evaluate dimensional changes (shrinkage and expansion) as a function of time, temperature and humidity. These forms are shown in Figures 2-7 (a) and (b). Shrinkage and bonding to the steel forms for the selected mixes and for a shrinkage compensating mix was postponed by Tank Closure Project personnel.

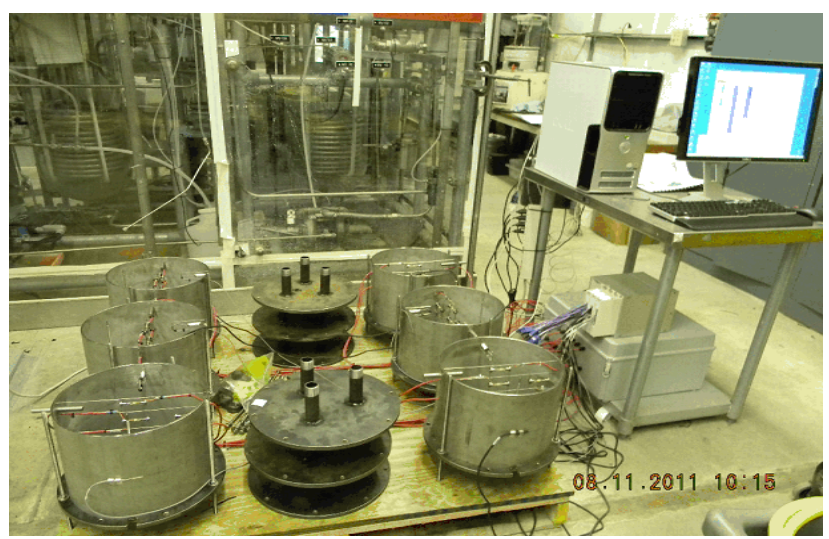

(a)

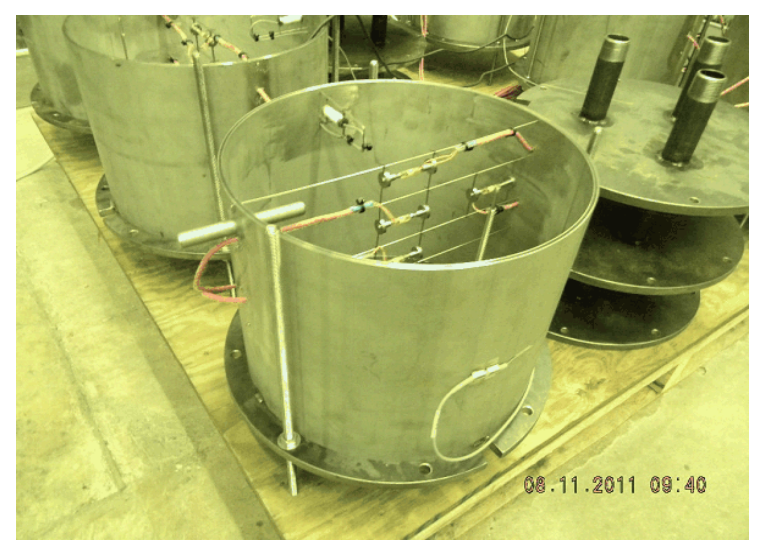

(b)

Figure 2-7. Shrinkage measurement forms and instrumentation. 
SRNL-STI-2011-00551

Revision 1

\subsection{RESULTS}

Results for two flowable zero bleed structural fill concepts containing 3/8 inch gravel (70070 Series and LP\#8 Series) and a sand only mix (SO Series) are provided in this report. Tank Farm Engineering and SRNL Project Management selected the $70070 \mathrm{mix}$ as the base case for inclusion in Revision 0 of the Tanks 18-F and 19-F grout procurement specification [Forty, $2011 \mathrm{a}$ ] and requested admixture recommendations and property confirmation for this formulation. Lower cementitious paste mixes were formulated because the $70070 \mathrm{mix}$ is over designed with respect to strength and generates more heat from hydration reactions than is desirable for mass pour application. Work was also initiated on a modification of the recommended mix which included shrinkage compensation to mitigate fast pathways caused by shrinkage cracking and poor physical bonding to the tank and ancillary equipment. Testing of this option was postponed.

\subsection{Mix 70070 and Modification}

Tank Farm Engineering and SRNL project management personnel selected Mix 70070 from an earlier report [Langton, et. al, 2007] and requested that the admixtures for this mix be updated so it could be incorporated in the 2011 specification for tank closure grout as a base case formulation [Jolly, 2011]. Currently available admixtures were identified and proportioned to achieve fresh properties (ASTM C1611 slump flow) comparable to those in the 2007 report. Results for the original 70070 mix design and mix 70070 with new admixtures are provided in Table 3-1.

The 70070 mix contains a large amount of paste (cement plus slag plus fly ash) and has relatively low water to cementitious materials ratio, 0.391. Both of these features contribute to two issues that make selection of this grout for closing Tanks 18-F and 19-F problematic: 1) high heat of hydration and 2) high viscosity of the paste fraction which can be interpreted as requiring a longer time for the grout to spread in the tank. ${ }^{3}$ Although the ASTM C1611 flow and compressive strength are excellent (> 28 inches), this type of mix is very cohesive. Consequently it will take longer to spread out in the tank than a mix with a lower viscosity which can be achieved with a higher water to cementitious materials ratio and / or less paste.

Given the project decision to use an off-site supplier to batch the tank fill grout and deliver it by truck to the F-Tank Farm, logistical issues which disrupt a steady discharge into the tanks were assumed to be likely. Disruptions in flow will reduce the amount of spread in the tank especially for a high viscosity cohesive mix like 70070. To increase grout flow / spreading under these conditions, a series of modified 70070 trial mixes were designed and tested.

These mix proportions and properties are also provided in Table 3-1. Mixes containing a range of cement contents, 185, 150, 125, and 100 pounds per cubic yard and a lower slag content 210 rather than 260 pounds per cubic yard were tested. All of the mixes in this series had a high paste content. The amount of reactive material was reduced and replaced with an equivalent volume of fly ash and / or water. Consequently, the heat of hydration was lowered, but the rheology was not significantly improved. The flow according to ASTM C1611 was excellent for all of the mixes. However, all of the mixes in this series were very cohesive. Some mixes were described as sticky and were especially difficult to scrape off of the flow board a few minutes after completion of the test. This feature is undesirable when flow and self-leveling in a tank 85 feet in diameter are required. Consequently this series was not recommended for closing Tanks 18-F and 19-F.

\footnotetext{
${ }^{3}$ The high amount of solids per unite volume and the high solids to water ratio results in a mix with a higher apparent viscosity relative to other mixes tested.
} 
Table 3-1. Ingredients, Proportions and Properties for the FTF 70070 Series of Tank Fill Grout Trial Mixes.

\begin{tabular}{|c|c|c|c|c|c|c|c|c|c|c|c|c|}
\hline $\begin{array}{l}\text { FTF } 70070 \text { Series } \\
\text { Ingredient (lbs/cyd) }\end{array}$ & $\begin{array}{l}\text { l11 Spec } \\
\text { Rev.0 } \\
\text { from } \\
\text { WSRC-STI- } \\
\text { 2007-00641) }\end{array}$ & $\begin{array}{c}\text { Modified } \\
\text { 2011 Spec } \\
\text { Rev. 0 } \\
\text { w/ new } \\
\text { Admixtures }\end{array}$ & Mod 8 & $\operatorname{Mod} 4$ & Mod 7 & Mod 6b & Mod 6c & Mod 5 & Mod 5b & Mod 1 & Mod 2 & Mod 3 \\
\hline $\mathbf{w} / \mathbf{c m}_{\text {total }}$ & 0.391 & 0.391 & 0.391 & 0.391 & 0.391 & 0.391 & 0.391 & 0.391 & 0.391 & 0.412 & 0.412 & 0.412 \\
\hline Portland Cement, Type I/II & 185 & 185 & 125 & 185 & 150 & 125 & 125 & 100 & 100 & 185 & 185 & 185 \\
\hline Slag Cement Grade 100 & 260 & 260 & 260 & 210 & 210 & 210 & 210 & 210 & 210 & 260 & 260 & 260 \\
\hline Fly Ash, Class F & 850 & 850 & 892 & 887 & 912 & 930 & 930 & 947 & 947 & 740 & 720 & 720 \\
\hline Concrete Sand, Quartz & 942 & 942 & 865 & 859 & 865 & 868 & 868 & 871 & 871 & 942 & 1040 & 1040 \\
\hline $\begin{array}{l}\text { Gravel, No. } 8 \text { Stone } \\
\text { 3/8in. crushed granite }\end{array}$ & 946 & 946 & 860 & 861 & 865 & 870 & 870 & 874 & 874 & 946 & 946 & 946 \\
\hline $\begin{array}{l}\text { Water (lb/cyd) } \\
\text { (gallons/cyd) }\end{array}$ & $\begin{array}{l}506 \\
60.7 \\
\end{array}$ & $\begin{array}{l}506 \\
60.7 \\
\end{array}$ & $\begin{array}{l}491.1 \\
59.0\end{array}$ & $\begin{array}{l}500.9 \\
60.1 \\
\end{array}$ & $\begin{array}{l}497.0 \\
59.7\end{array}$ & $\begin{array}{c}494.2 \\
59.3\end{array}$ & $\begin{array}{c}494.2 \\
59.3\end{array}$ & $\begin{array}{c}491.1 \\
59.0\end{array}$ & $\begin{array}{c}491.1 \\
59.0\end{array}$ & $\begin{array}{l}506 \\
60.7 \\
\end{array}$ & $\begin{array}{l}480 \\
57.6\end{array}$ & $\begin{array}{l}480 \\
57.6\end{array}$ \\
\hline $\begin{array}{l}\text { HRWR SIKA ViscoCrete } 2100 \\
\text { (fl oz/cyd) }\end{array}$ & $\begin{array}{c}54 \\
\text { Advaflex } \\
\end{array}$ & $\begin{array}{c}41 \\
\text { Sika } 2100 \\
\end{array}$ & 40.5 & 40.5 & 29 & 41 & 30 & 40.5 & 27 & 27 & 27 & 27 \\
\hline $\begin{array}{l}\text { VMA, Kelco CP, Diutan Gum } \\
\text { (g/cyd) }\end{array}$ & \begin{tabular}{|c|}
216 \\
Welan Gum \\
\end{tabular} & \begin{tabular}{c|}
162 \\
Diutan Gum \\
\end{tabular} & 162 & 162 & 122 & 162 & 162 & 162 & 162 & 108 & 108 & 162 \\
\hline \multicolumn{13}{|l|}{ Fresh Properties } \\
\hline Slump Flow, ASTM C1611 (in.) & 31.5 & 30.5 & 28.75 & 31 & 29.25 & 34.5 & 28 & 36 & 28 & 31 & 26 & 24 \\
\hline $\begin{array}{l}\text { Spread, ASTM D-6103 (in.) } \\
\text { Static time after mixing (min) }\end{array}$ & $\mathrm{t}_{0}=12.5$ & $\begin{array}{l}t_{0}=13.0 \\
t_{55}=7.5\end{array}$ & $\begin{array}{c}t_{0}=13.75 \\
t_{57}=0\end{array}$ & $\begin{array}{l}\mathrm{t}_{0}=13.5 \\
\mathrm{t}_{38}=6.5\end{array}$ & $\begin{array}{c}\mathrm{t}_{0}=14.25 \\
\mathrm{t}_{30}=0\end{array}$ & NM & $\begin{array}{c}\mathrm{t}_{0}=13.75 \\
\mathrm{t}_{30}=8.0\end{array}$ & $\begin{array}{l}t_{0}=16.5 \\
t_{35}=14\end{array}$ & $\begin{array}{l}t_{0}=12.25 \\
t_{30}=5.75\end{array}$ & NM & $\mathrm{t}_{0}=9$ & $\begin{array}{l}\mathrm{t}_{0}=10.0 \\
\mathrm{t}_{30}=9.0\end{array}$ \\
\hline Air Content (vol. \%) & 1.7 & 0.9 & 1.5 & 1.6 & 1.5 & 1.5 & 1.8 & 1.3 & 2.1 & 0.8 & 1.6 & 1.9 \\
\hline Set Time (hr.) & $<24$ & $<20.5$ & $<20$ & $<20.5$ & $<16$ & NM & $<15$ & $<16$ & $<15$ & $<18$ & $<18$ & $<24$ \\
\hline Bleed (ml) & 0 & $\begin{array}{l}7 \mathrm{ml}(10 \mathrm{~h}) \\
0 \mathrm{ml}(24 \mathrm{hr})\end{array}$ & 0 & 0 & 0 & NM & 0 & 0 & 0 & 124 & 29 & 11 \\
\hline Unit Weight (lbs/cft) & 132.3 & 129.72 & 127.64 & 127.72 & 129.44 & 130.45 & 129.44 & 127.84 & 127.03 & 129.85 & 132.66 & 131.38 \\
\hline \multicolumn{13}{|l|}{ Cured Properties } \\
\hline \multicolumn{13}{|l|}{ Compressive Strength (psi) } \\
\hline 7 days & NM & 820 & 870 & 740 & 460 & NM & 590 & 610 & 560 & 890 & 780 & 790 \\
\hline 28 days & 3440 & 4185 & 3750 & 3715 & 3185 & NM & 3135 & 2920 & 2915 & 4235 & 3735 & 3780 \\
\hline 90 days & 4840 & 6005 & 4975 & 6110 & 4585 & NM & 4205 & 4235 & 3920 & 5875 & 5525 & 5855 \\
\hline 180 days & 5970 & NM & NM & NM & NM & NM & NM & NM & NM & NM & NM & NM \\
\hline $\begin{array}{l}\text { Sat. Hydraulic Conductivity k ksat@20 } \\
\text { ASTM D5084 Method C (cm/s) }\end{array}$ & $6.60 \mathrm{E}-09$ & $5.5 \mathrm{E}-09$ & 4.2E-09 & $2.8 \mathrm{E}-09$ & 3.7E-09 & NM & $2.2 \mathrm{E}-09$ & $5.5 \mathrm{E}-09$ & TBD & $2.4 \mathrm{E}-09$ & $2.0 \mathrm{E}-09$ & 4.6E-09 \\
\hline Shrinkage (\%) & NM & NM & NM & NM & NM & NM & NM & NM & NM & NM & NM & NM \\
\hline Settlement & NM & $\begin{array}{c}\text { small } \\
\text { amount }\end{array}$ & none & $\begin{array}{c}\text { small } \\
\text { amount }\end{array}$ & none & some & none & considerable & none & NM & NM & NM \\
\hline Adiabatic Temperature Rise $\left({ }^{\circ} \mathrm{C}\right)$ & NM & NM & NM & NM & NM & NM & NM & NM & NM & NM & NM & 44.7 \\
\hline $\begin{array}{l}\text { Maximum Calorimeter Temperature } \\
\text { for starting temperature } 24^{\circ} \mathrm{C}\left({ }^{\circ} \mathrm{C}\right)\end{array}$ & NM & NM & NM & NM & NM & NM & NM & NM & NM & NM & NM & $\begin{array}{c}\mathrm{T}_{\mathrm{i}}=24 \\
\mathrm{~T}_{\mathrm{f}}=54.2 \\
\end{array}$ \\
\hline Date prepared & & $6 / 1 / 2011$ & 6/9/2011 & 6/1/2011 & 6/8/2011 & 6/8/2011 & 6/8/2011 & $6 / 1 / 2011$ & $6 / 1 / 2011$ & 4/5/2011 & 4/5/2011 & $4 / 6 / 2011$ \\
\hline Comments & NM & NM & NM & NM & NM & NM & sticky & NM & sticky & NM & sticky & sticky \\
\hline
\end{tabular}




\subsection{Sand Only All-In-One Mix Series}

A second base case mix, a sand only all-in-one zero bleed reducing grout, OPCEXE-X-P-O-BS, which was included in a 2007 draft tank fill grout specification, C-SPP-F-00047 Rev 2, was also evaluated. The properties of this mix were used in the current FTF PA [SRS, 2007]. New admixture doses were identified for this mix and modifications were made to this mix to increase the 28 day strength ( $>2000 \mathrm{psi})$. The water to cementitious materials ratio which is relatively high, 0.757 was decreased and more cement was added. An equivalent volume of fly ash was removed to account for the additional cement. The proportions and properties of the sand only (SO) all-in-one mixes with the new admixture doses are listed in Table 3-2.

Increasing the amount of cement in the modified mixes from 100 to 185 pounds per cubic yard had a larger effect on the 90 day strengths than on the 28 day strengths. Decreasing the water to cementitious ratio by 0.05 (from 0.757 to 0.707 ) also consistently increased the 90 day compressive strengths by at least 300 psi for the formulations tested. The SO series of mixes were flowable after standing for 30 minutes under static conditions. Consequently, even though the ASTM C1611 flows were not as large as mixes with gravel, this mix concept is suitable for filling tanks that require flow over $45 \mathrm{ft}$.

Full scale mock up testing of this type of mix is not a high priority because a similar mix was used as the bulk fill for Tanks 17-F and 20-F. However, during the Tank 17-F and 20-F closure, admixture adjustments during on-site production were required to keep the production grout flowable. Such adjustments would add extra steps and testing to preparing and trucking grout from off site or adjusting admixtures in the truck at the point of delivery.

\subsection{LP\#8 Series}

The first alternative grout designed for filling Tanks 18-F and 19-F was based on previous experience in designing robust self-leveling, flowable structural fills for in-situ decommissioning $105 \mathrm{P}$ - and R-Reactor facilities during 2010 and 2011. The ingredients, proportions, and properties for the grout used to fill the bulk of the below grade portions of these structures are listed in Table 3-3. The reactor grout did not meet the chemical requirements (no slag) and all of the cured property requirements (compressive strength) for tank closure. However, it had excellent flow, self leveling, and zero bleed characteristics. Consequently, this mix concept was modified by adding slag, adjusting the cement content, and lowering the water to cementitious materials ratios from 0.641 to a range between 0.610 and 0.500 . This series of mixes is referred to as the LP\#8 Series (low paste with No. 8 stone).

This mix concept is robust. Mixes with water to cementitious materials ratios between 0.610 and 0.500 met the flow requirements. All of the mixes with as little as 100 pounds of Portland cement plus 210 pounds of Grade 100 slag per cubic yards met the strength requirements. Consequently, this mix concept is best suited for the tank closure fill grout. Mix LP\#8-16 was recommended for Tank 18-F and 19-F grout specification based on data collected to date [Langton and Stefanko, 2011]. Pending permeability results, a mix with a lower water to cementitious materials ratio, LP\#8-20 was also recommended as an alternative. 
Table 3-2. Ingredients, Proportions and Properties for the Sand Only (SO) Series of Tank Fill Grout Trial Mixes

\begin{tabular}{|c|c|c|c|c|c|c|c|c|c|c|c|c|}
\hline SO Series & \begin{tabular}{|c|}
$\begin{array}{c}\text { All-In-One } \\
\text { (new admix) }\end{array}$ \\
w/cm = 0.757 \\
WSRC-STI- \\
2007-00641 \\
\end{tabular} & \multicolumn{5}{|c|}{ SO Series 1: $\mathbf{w} / \mathbf{c m}_{\text {total }}=0.757$} & \multicolumn{4}{|c|}{ SO Series 2: $\mathbf{w} / \mathbf{c m}_{\text {total }}=\mathbf{0 . 7 0 7}$} & \multirow{2}{*}{$\frac{0.657}{10}$} & \multirow{2}{*}{$\frac{0.682}{10 b}$} \\
\hline Ingredient (Lb/cyd) Mix No. & SO-001b & 2 & 3 & $3 \mathbf{b}$ & 4 & $5 \mathbf{b}$ & $6 \mathbf{b}$ & 7 & 8 & 9 & & \\
\hline Portland Cement, Type I/II & 75 & 100 & 125 & 125 & 150 & 185 & 100 & 125 & 150 & 185 & 100 & 100 \\
\hline Slag Cement Grade 100 & 210 & 210 & 210 & 210 & 210 & 210 & 210 & 210 & 210 & 210 & 210 & 210 \\
\hline Fly Ash, Class F & 375 & 357 & 340 & 340 & 322 & 297 & 357 & 340 & 322 & 297 & 357 & 357 \\
\hline Concrete Sand, Quartz & 2300 & 2355 & 2337 & 2337 & 2323 & 2303 & 2442 & 2425 & 2413 & 2395 & 2530 & 2486 \\
\hline Gravel, No. 8 Stone, & 0 & 0 & 0 & 0 & 0 & 0 & 0 & 0 & 0 & 0 & 0 & 0 \\
\hline $\begin{array}{l}\text { Water (lb/cyd) } \\
\text { (gallons/cyd) }\end{array}$ & $\begin{array}{c}499.6 \\
60\end{array}$ & $\begin{array}{l}504.9 \\
60.6\end{array}$ & $\begin{array}{c}511.0 \\
1.3\end{array}$ & $\begin{array}{l}511.0 \\
61.3\end{array}$ & $\begin{array}{c}516.30 \\
62.0\end{array}$ & $\begin{array}{c}523.8 \\
62.9\end{array}$ & $\begin{array}{l}471.6 \\
56.6\end{array}$ & $\begin{array}{c}477.2 \\
57.3\end{array}$ & $\begin{array}{c}482.2 \\
57.9\end{array}$ & $\begin{array}{c}489.2 \\
58.7\end{array}$ & $\begin{array}{c}438.2 \\
52.6\end{array}$ & $\begin{array}{c}454.9 \\
54.6\end{array}$ \\
\hline $\begin{array}{l}\text { HRWR SIKA ViscoCrete } 2100 \\
\text { (fl oz/cyd) }\end{array}$ & 27 & 27 & 27 & 41 & 27 & 36 & 45 & 50 & 45 & 45 & 72 & 72 \\
\hline $\begin{array}{l}\text { VMA, Kelco CP, Diutan Gum } \\
\text { (g/cyd) }\end{array}$ & 169.92 & 170.64 & 169.92 & 170 & 169.92 & 169.92 & 135 & 135 & 135 & 135 & 81 & 135 \\
\hline \multicolumn{13}{|l|}{ Fresh Properties } \\
\hline $\begin{array}{l}\text { Slump Flow, ASTM } \\
\text { C1611(in.) }\end{array}$ & 25 & 24.5 & 23.75 & 25 & 22.75 & 25.63 & 23.25 & 23.75 & 24.13 & 23.5 & 16.75 & 20.5 \\
\hline $\begin{array}{l}\text { Spread, ASTM D-6103 (in.) } \\
\text { after mixing and after static } \\
\text { period (min) }\end{array}$ & $\begin{array}{l}\mathrm{t}_{0}=10.0 \\
\mathrm{t}_{30}=9.0\end{array}$ & $\begin{array}{l}t_{0}=10.0 \\
t_{30}=9.25\end{array}$ & $\begin{array}{l}t_{0}=10.5 \\
t_{30}=6.0\end{array}$ & $\begin{array}{l}\mathrm{t}_{0}=11.25 \\
\mathrm{t}_{30}=10.5\end{array}$ & $\begin{array}{l}\mathrm{t}_{0}=11.62 \\
\mathrm{t}_{30}=4.75\end{array}$ & $\begin{array}{l}\mathrm{t}_{0}=12.5 \\
\mathrm{t}_{30}=8.0\end{array}$ & $\begin{aligned} \mathrm{t}_{0} & =10.0 \\
\mathrm{t}_{30} & =11.25\end{aligned}$ & $\begin{array}{l}t_{0}=10.5 \\
t_{30}=9.75\end{array}$ & $\begin{array}{l}t_{0}=10.0 \\
t_{30}=9.25\end{array}$ & $\begin{array}{l}t_{0}=9.75 \\
t_{30}=7.75\end{array}$ & $\begin{array}{l}t_{0}=5.75 \\
t_{30}=6.0\end{array}$ & $\begin{array}{l}\mathrm{t}_{0}=8.0 \\
\mathrm{t}_{30}=6.0\end{array}$ \\
\hline Air Content (vol. \%) & 3.6 & 3.3 & 3.5 & 3.3 & 3.8 & 2.0 & 4.0 & 2.8 & 3.1 & 3.1 & 5.5 & 5 \\
\hline Set Time (hr.) & $<24$ & $<24$ & $<20$ & $<13$ & $<19$ & $<15$ & $<18$ & $<17$ & $<16$ & $<15$ & NM & $<24$ \\
\hline Bleed (ml) & 0 & 0 & 0 & 0 & 0 & 0 & 0 & 0 & 0 & 0 & 8 & 0 \\
\hline Unit Weight (lbs/cft) & 126.63 & 127.43 & 126.43 & 126.03 & 126.23 & 128.24 & 127.64 & 129.44 & 128.24 & 128.64 & 127.2 & 127 \\
\hline \multicolumn{13}{|l|}{ Cured Properties } \\
\hline \multicolumn{13}{|l|}{ Compressive Strength (psi) } \\
\hline 7 days & 270 & 210 & 230 & 280 & 260 & 310 & 260 & 300 & 320 & 400 & NM & 340 \\
\hline 28 days & 1790 & 1810 & 1770 & 1820 & 1960 & 2055 & 1880 & 2105 & 2120 & 2270 & NM & 2030 \\
\hline 90 days & 3530 & 3020 & 3450 & 3380 & 3730 & 3875 & 3465 & 4085 & 4160 & 4415 & NM & 3285 \\
\hline $\begin{array}{l}\text { Sat. Hydraulic Conductivity k ksat@20 } \\
\text { ASTM D5084 Method C (cm/s) }\end{array}$ & 6.3E-09 & $2.4 \mathrm{E}-09$ & $1.2 \mathrm{E}-09$ & 2.0E-09 & 4.5E-09 & $2.4 \mathrm{E}-09$ & 3.0E-09 & 2.1E-09 & 2.2E-09 & 3.0E-09 & NM & 3.1E-09 \\
\hline Shrinkage (\%) & NM & NM & NM & NM & NM & NM & NM & NM & NM & NM & NM & NM \\
\hline $\begin{array}{l}\text { Adiabatic Temperature Rise } \\
\left({ }^{\circ} \mathrm{C}\right)\end{array}$ & 27.2 & NM & NM & NM & NM & NM & NM & NM & NM & NM & NM & NM \\
\hline $\begin{array}{l}\text { Maximum Temperature given } \\
\text { starting temperature of } 24^{\circ} \mathrm{C} \\
\left({ }^{\circ} \mathrm{C}\right)\end{array}$ & $\begin{array}{c}\mathrm{T}_{\mathrm{i}}=24 \\
\mathrm{~T}_{\mathrm{f}}=42.2\end{array}$ & NM & NM & NM & NM & NM & NM & NM & NM & NM & NM & NM \\
\hline Date prepared & $5 / 19 / 2011$ & $5 / 19 / 2011$ & $5 / 24 / 2011$ & $5 / 31 / 2011$ & $5 / 24 / 2011$ & $5 / 24 / 2011$ & $5 / 25 / 2011$ & $5 / 25 / 2011$ & $5 / 25 / 2011$ & $5 / 25 / 2011$ & $5 / 26 / 2011$ & $5 / 26 / 2011$ \\
\hline
\end{tabular}


Table 3-3. Ingredients, Proportions and Properties for Low Paste with No. 8 Stone (LP\#8) Series of Tank Fill Grout Trial Mixes.

\begin{tabular}{|c|c|c|c|c|c|c|c|c|c|c|c|c|c|c|c|c|c|}
\hline \multirow{2}{*}{$\begin{array}{l}\text { LP\#8 Series } \\
\text { Ingredient (Lb/cyd) }\end{array}$} & \multirow{2}{*}{\begin{tabular}{||c||} 
Reactor Fill \\
w/cm $=$ \\
0.641 \\
\end{tabular}} & \multicolumn{4}{|c|}{ LP\#8 Series 1: $w / \mathrm{cm}_{\text {total }}=0.610$} & \multicolumn{4}{|c|}{ LP\#8 Series 2: $w / \mathrm{cm}_{\text {total }}=0.580$} & \multicolumn{4}{|c|}{ LP\#8 Series 3: $w / \mathrm{cm}_{\text {total }}=0.550$} & \multicolumn{4}{|c|}{ LP\#8 Series 4: $\mathrm{w} / \mathrm{cm}_{\text {total }}=\mathbf{0 . 5 0 0}$} \\
\hline & & 12 & 14 & 11 & 13 & 15 & 16 & 17 & 18 & $19 b$ & 20 & 21 & 22 & 25 & 23 & 24 & 26 \\
\hline Portland Cement, Type I/II & 150 & 100 & 125 & 150 & 185 & 100 & 125 & 150 & 185 & 100 & 125 & 150 & 185 & 100 & 125 & 150 & 185 \\
\hline Slag Cement Grade 100 & 0 & 210 & 210 & 210 & 210 & 210 & 210 & 210 & 210 & 210 & 210 & 210 & 210 & 260 & 260 & 260 & 260 \\
\hline Fly Ash, Class F & 500 & 380 & 363 & 345 & 320 & 380 & 363 & 345 & 320 & 380 & 363 & 345 & 320 & 418 & 400 & 383 & 358 \\
\hline Concrete Sand, Quartz & 1850 & 1750 & 1735 & 1750 & 1708 & 1805 & 1790 & 1778 & 1765 & 1860 & 1847 & 1837 & 1822 & 1635 & 1630 & 1621 & 1613 \\
\hline $\begin{array}{l}\text { Gravel, No. } 8 \\
\text { 3/8 inch Crushed Granite }\end{array}$ & 800 & 800 & 800 & 800 & 800 & 800 & 800 & 800 & 800 & 800 & 800 & 800 & 800 & 973 & 970 & 965 & 960 \\
\hline $\begin{array}{l}\text { Water (lb/cyd) } \\
\text { (gallons/cyd) }\end{array}$ & $\begin{array}{c}416.5 \\
50.0\end{array}$ & $\begin{array}{c}420.9 \\
50.5\end{array}$ & $\begin{array}{c}425.8 \\
51.1\end{array}$ & $\begin{array}{c}430.0 \\
50.5\end{array}$ & $\begin{array}{c}436.2 \\
52.4\end{array}$ & $\begin{array}{c}400.2 \\
48.0\end{array}$ & $\begin{array}{c}404.8 \\
48.6\end{array}$ & $\begin{array}{c}408.9 \\
49.1\end{array}$ & $\begin{array}{r}414.7 \\
49.8\end{array}$ & $\begin{array}{c}379.5 \\
45.6\end{array}$ & $\begin{array}{c}383.90 \\
46.1\end{array}$ & $\begin{array}{c}387.8 \\
46.5\end{array}$ & $\begin{array}{c}393.3 \\
47.2\end{array}$ & $\begin{array}{c}387.8 \\
46.5\end{array}$ & $\begin{array}{c}392.5 \\
47.1\end{array}$ & $\begin{array}{c}396.5 \\
47.6\end{array}$ & $\begin{array}{c}401.5 \\
48.2\end{array}$ \\
\hline $\begin{array}{l}\text { HRWR SIKA ViscoCrete } \\
2100 \text { (fl oz/cyd) }\end{array}$ & 79 & 49.5 & 45 & 36 & 49.5 & 40.5 & 40.5 & 40.5 & 40.5 & 54 & 54 & 45 & 54 & 45 & 45 & 54 & 45 \\
\hline $\begin{array}{l}\text { VMA, Kelco CP, Diutan } \\
\text { Gum (g/cyd) }\end{array}$ & 205 & 200.16 & 200.16 & 199.8 & 200.16 & 200.16 & 200.16 & 200.16 & 200.16 & 120.24 & 155.16 & 119.16 & 120.24 & 162 & 162 & 162 & 162 \\
\hline \multicolumn{18}{|l|}{ Fresh Properties } \\
\hline $\begin{array}{l}\text { Slump Flow, } \\
\text { ASTM C1611 (in.) }\end{array}$ & $24 \pm 4$ & 25.75 & 28.25 & 26 & 28 & 27.5 & 25.75 & 27 & 25 & 25 & 24.5 & 25.25 & 27 & 26 & 25.25 & 26 & 24 \\
\hline Air Content (vol. \%) & $<8$ & 1.5 & 1.3 & 1.6 & 1.5 & 1.2 & 2 & 1.5 & 2.2 & 2.8 & 2.5 & 2.1 & NM & 1.7 & 1.6 & 1.6 & 1.7 \\
\hline Set Time (hr.) & $<24$ & $<24$ & $<24$ & $<24$ & $<24$ & $<24$ & $<18$ & $<18$ & $<18$ & $<20$ & $<24$ & $<24$ & $<24$ & $<19$ & $<19$ & $<20$ & $<17$ \\
\hline Bleed (ml) & 0 & 0 & 0 & 0 & 0 & 0 & 0 & 0 & 0 & 0 & 0 & 0 & 0 & 0 & 0 & 0 & 0 \\
\hline Unit Weight (lbs/cft) & NA & 134.94 & 133.9 & 132.86 & 134.94 & 133.33 & 133.67 & 132.26 & 134.27 & 133.67 & 132.86 & 133.67 & 132.86 & \begin{tabular}{|l|}
136.68 \\
\end{tabular} & 136.68 & 137.89 & 137.89 \\
\hline $\begin{array}{l}\text { Spread, ASTM D-6103 (in.) } \\
\text { after static period (min) }\end{array}$ & NM & NM & NM & NM & NM & NM & $\begin{array}{c}t_{30}= \\
9.5 \text { in. }\end{array}$ & NM & NM & NM & $\begin{array}{l}\mathrm{t}_{30}= \\
9 \text { in. }\end{array}$ & NM & NM & \begin{tabular}{|l}
$\mathrm{t}_{0}=12.5$ \\
$\mathrm{t}_{35}=12.5$
\end{tabular} & $\begin{array}{l}t_{0}=11.5 \\
36=10.75\end{array}$ & $\begin{array}{l}\mathrm{t}_{0}=11.75 \\
\mathrm{t}_{32}=11.5\end{array}$ & $\begin{array}{l}\mathrm{t}_{0}=10.5 \\
\mathrm{t}_{40}=7.5\end{array}$ \\
\hline \multicolumn{18}{|l|}{ Cured Properties } \\
\hline \multicolumn{18}{|l|}{ Compressive Strength (psi) } \\
\hline 7 days (1) & $\sim 250$ & 340 & 190 & 410 & 280 & 160 & 370 & 360 & 490 & 360 & 360 & 480 & 590 & 970 & 970 & 950 & 1010 \\
\hline 28 days (2) & $\sim 780$ & 2335 & 2575 & 2500 & 3045 & 2300 & 2680 & 2495 & 2940 & 2560 & 2465 & 3090 & 3110 & 3780 & 4145 & 4585 & 5155 \\
\hline 90 days & $\sim 1640$ & 3815 & 4595 & 4185 & 5040 & 3705 & 4560 & 4530 & 5270 & 4060 & 4395 & 5205 & 5100 & 5020 & 5830 & 6855 & 7280 \\
\hline $\begin{array}{l}\text { Sat. Hydraulic Conductivity } \\
\text { k }_{\text {hsat } @ 20} \text { ASTM D5084 } \\
\text { Method C, URS Data (cm/s) }\end{array}$ & $1.30 \mathrm{E}-08$ & NM & NM & $3.2 \mathrm{E}-09$ & NM & $3.1 \mathrm{E}-09$ & 2.1E-09 & $2.4 \mathrm{E}-09$ & NM & 2.5E-09 & \begin{tabular}{|c|} 
See Section \\
3.5
\end{tabular} & 4.2E-09 & $2.0 \mathrm{E}-09$ & 2.1E-09 & 1.1E-09 & 2.0E-09 & .3.E-09 \\
\hline Shrinkage (\%) & NM & NM & NM & NM & NM & NM & NM & NM & NM & NM & NM & NM & NM & NM & NM & NM & NM \\
\hline Porosity & NM & NM & NM & NM & NM & NM & 0.21 & NM & NM & NM & 0.21 & NM & NM & NM & NM & NM & NM \\
\hline Settlement/segregation & NM & NM & none & none & none & none & none & none & none & none & none & none & none & none & none & none & none \\
\hline $\begin{array}{l}\text { Adiabatic Temperature Rise } \\
\left({ }^{\circ} \mathrm{C}\right)\end{array}$ & $<25$ & NM & NM & NM & NM & NM & NM & NM & NM & NM & NM & 41 & NM & NM & NM & 37.2 & NM \\
\hline $\begin{array}{l}\text { Maximum Temperature for } \\
\text { starting temperature of }\left({ }^{\circ} \mathrm{C}\right)\end{array}$ & NM & NM & $\mathrm{NM}$ & $\mathrm{NM}$ & $\mathrm{NM}$ & NM & NM & NM & $\mathrm{NM}$ & NM & NM & $\begin{array}{l}\mathrm{T}_{\mathrm{i}}=22.0 \\
\mathrm{~T}_{\mathrm{f}}=49.9\end{array}$ & NM & NM & NM & $\begin{array}{l}\mathrm{T}_{\mathrm{i}}=25.0 \\
\mathrm{~T}_{\mathrm{f}}=51.5\end{array}$ & NM \\
\hline Date prepared & & $5 / 12 / 2011$ & 5/12/2011 & $5 / 11 / 2011$ & $5 / 12 / 2011$ & 5/12/2011 & $5 / 16 / 2011$ & $5 / 16 / 2011$ & $5 / 16 / 2011$ & $5 / 16 / 2011$ & $5 / 17 / 2011$ & $5 / 17 / 2011$ & 5/17/2011 & 6/14/2011 & $6 / 9 / 2011$ & 6/14/2011 & $6 / 14 / 2011$ \\
\hline
\end{tabular}




\subsection{Thermal Property Characterization for Selected Mixes}

Adiabatic calorimetry was used to measure heats of hydration and adiabatic temperature increases for different grout compositions and was documented in a previous report [Steimke and Fowley, 1997]. Freshly mixed grout was placed in a stainless steel dewar which was placed inside a stirred bath of ethylene glycol. Half of a calibrated differential thermocouple was placed in the middle of the grout and the other half was placed in the bath. The calorimeter was programmed to add just enough heat to the bath to exactly match the temperatures of grout and bath. Because there was no temperature difference, no heat flowed in or out of the grout, which means adiabatic conditions.

Most of the heat generated by the hydrating grout was consumed in increasing the temperature of the grout, but some heat went to heating the thin plastic sleeve in the dewar, the inner surface of the dewar and the inner half of the rubber stopper in the dewar. The relationship for total heat generation rate in watts is provided below: where $\mathrm{M}$ and $\mathrm{Cp}$ are the masses and heat capacities of the grout and the other three components that absorb heat, respectively, and $\mathrm{T}_{\mathrm{c}}$ is the grout temperature in the calorimeter [Steimke and Fowley, 1997].

Equation 1. $\quad \mathrm{G}=\frac{\mathrm{dT}_{\mathrm{c}}}{\mathrm{dt}} \sum_{\mathrm{i}=1}^{4} \mathrm{M}_{\mathrm{i}} \mathrm{C}_{\mathrm{pi}}$

The total heat generated in joules is calculated by integrating Equation 1.

Equation 2. $\Delta \mathrm{H}=\Delta \mathrm{T}_{\mathrm{c}} \sum_{\mathrm{i}=1}^{4} \mathrm{M}_{\mathrm{i}} \mathrm{C}_{\mathrm{pi}}$

Rearranging Equation 2 for calorimeter temperature increase gives the following equation:

Equation 3. $\Delta \mathrm{T}_{\mathrm{c}}=\frac{\Delta \mathrm{H}}{\sum_{\mathrm{i}=1}^{4} \mathrm{M}_{\mathrm{i}} \mathrm{C}_{\mathrm{pi}}}$

For a massive pour of grout where the heat generated is consumed only by grout and not other objects in the experiment, the Equation 3 reduces to the following for adiabatic temperature increase where the subscript g refers to grout.

Equation 4. $\Delta \mathrm{T}_{\mathrm{a}}=\frac{\Delta \mathrm{H}}{\mathrm{M}_{\mathrm{g}} \mathrm{C}_{\mathrm{pg}}}$

Solving Equation 3 for $\Delta \mathrm{H}$ and substituting in Equation 4 gives the equation for adiabatic temperature increase for a large pour of grout.

Equation 5.

$$
\Delta \mathrm{T}_{\mathrm{a}}=\Delta \mathrm{T}_{\mathrm{c}} \frac{\sum_{\mathrm{i}=1}^{4} \mathrm{M}_{\mathrm{i}} \mathrm{C}_{\mathrm{pi}}}{\mathrm{M}_{\mathrm{g}} \mathrm{C}_{\mathrm{pg}}}
$$


Adiabatic calorimeter data for selected grouts are provided in Figures 3-1 and 3-2. A summary of the thermal properties including the adiabatic temperature rise for complete hydration and density are provided for selected mixes in Table 3-4.

The number of samples for which the adiabatic temperature rise was measured was limited due to the cost of these analyses. However, method of calculating temperature rise as a function of composition is being developed by SRNL / EDL personnel. The other thermal properties, i.e., specific heat and thermal conductivity, do not vary very much between samples within a mix series which supports using an estimated value in thermal transient calculations.

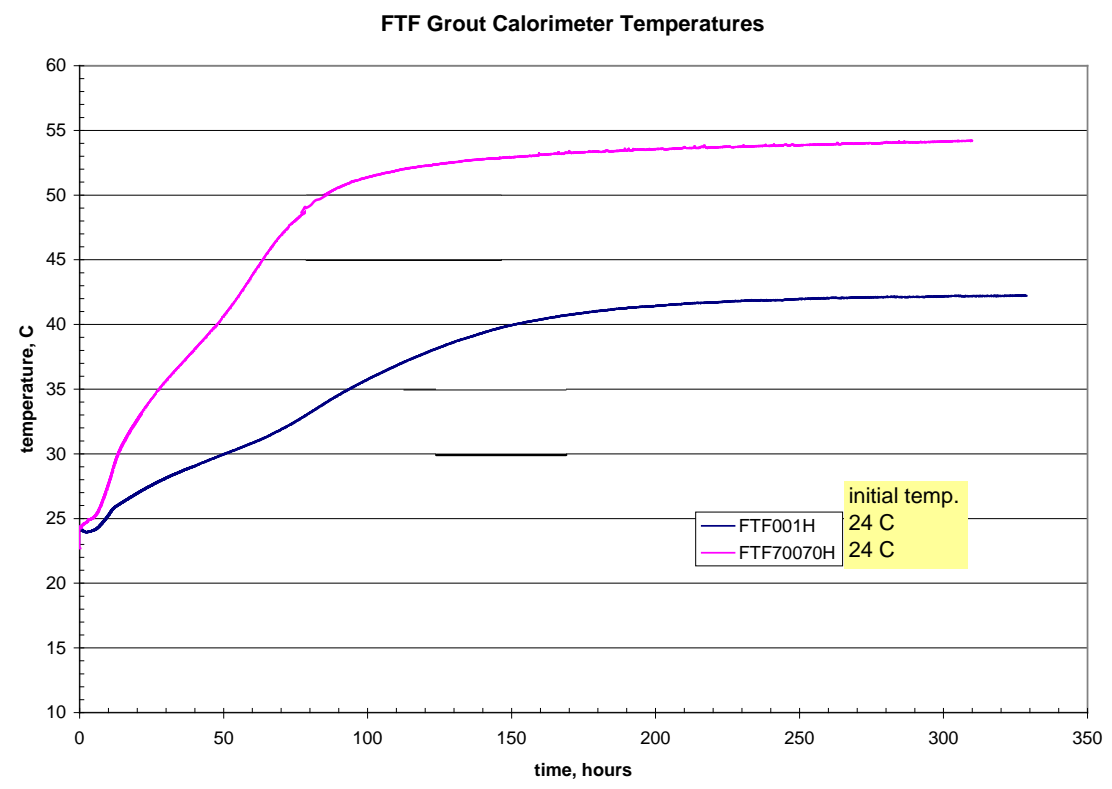

Figure 3-1. Adiabatic calorimeter data for Mixes FTF001H and FTF70070H. 
Grout LP8021

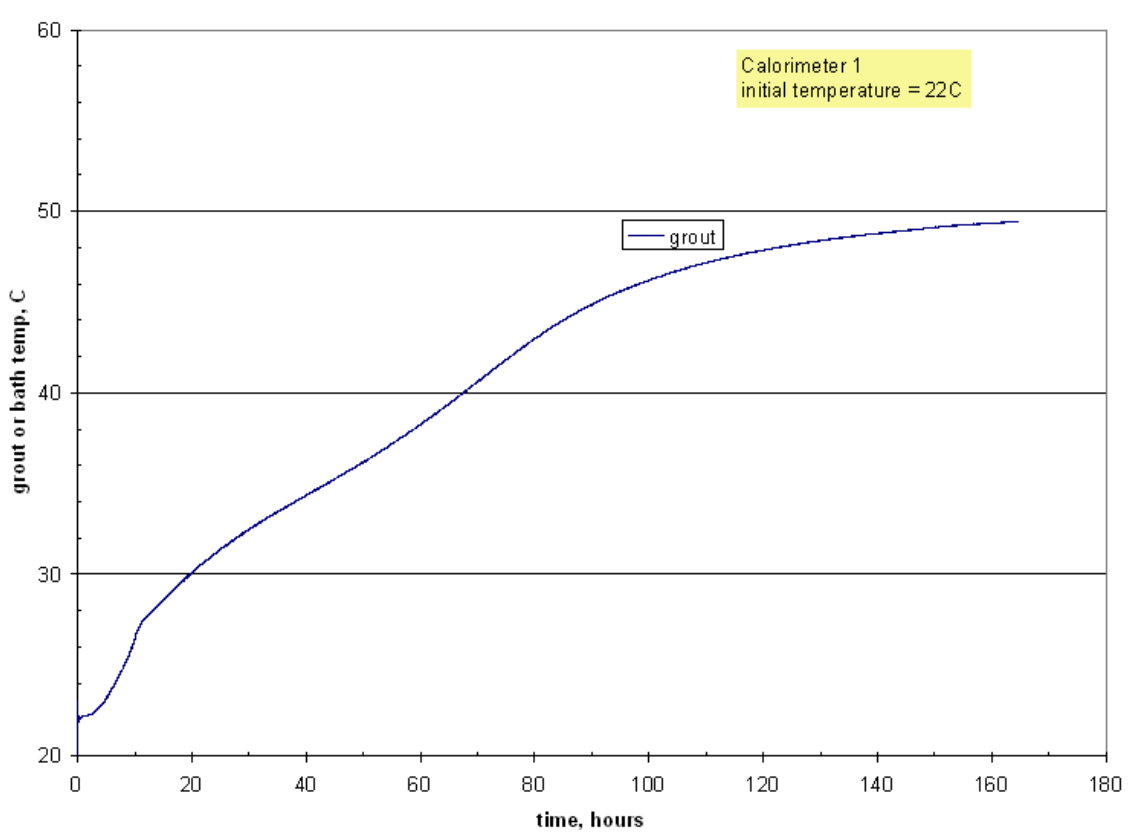

Figure 3-2. Adiabatic calorimeter data for Mix LP\#8-021H.

Table 3-4. Summary of thermal properties for representative mixes.

\begin{tabular}{|l|c|c|c|c|c|c|}
\hline Thermal Property & FTF70070H & $\begin{array}{c}\text { All-In-One } \\
\text { FTF-SO-001H }\end{array}$ & LP\#8-016 & LP\#8-020 & LP\#8-021H & LP\#8-024H \\
\hline Cement (lbs/cyd) & 185 & 75 & 125 & 125 & 150 & 150 \\
\hline Slag (lbs/cyd) & 260 & 210 & 210 & 210 & 210 & 260 \\
\hline $\begin{array}{l}\text { Adiabatic } \\
\text { Temperature Rise } \\
\text { for complete } \\
\left.\text { hydration ( }{ }^{\circ} \mathrm{C}\right)\end{array}$ & 44.7 & 27.2 & $34^{*}$ & $34^{*}$ & 41.0 & 37.2 \\
\hline Density (g/cm $\left.{ }^{3}\right)$ & 2.115 & 2.076 & $2.21^{*}$ & $2.21^{*}$ & 2.208 & 2.213 \\
\hline $\begin{array}{l}\text { Specific Heat } \\
\text { (cal/g-K) }\end{array}$ & 0.29 & 0.284 & $0.26^{*}$ & $0.26^{*}$ & 0.259 & 0.296 \\
\hline $\begin{array}{l}\text { Specific Heat } \\
\text { (J/kg-K) }\end{array}$ & 1214 & 1189 & $1080^{*}$ & $1080^{*}$ & 1082 & 1240 \\
\hline $\begin{array}{l}\text { Thermal } \\
\text { Conductivity } \\
\text { (W/m-K) }\end{array}$ & 2 & 2.5 & $2.5^{*}$ & $2.5^{*}$ & 2.45 & 2.45 \\
\hline $\begin{array}{l}\text { Thermal } \\
\text { Conductivity, J/mL }\end{array}$ & 115 & 67 & $85^{*}$ & $85^{*}$ & 98 & 102 \\
\hline
\end{tabular}

* Estimated

The maximum temperature of the mix was calculated by adding the adiabatic temperature rise to the starting temperature which in the experiments ranged from 22 to $24^{\circ} \mathrm{C}$. Under field conditions, the starting temperature of the grout ingredients can be $30^{\circ} \mathrm{C}$ or higher. For a maximum grout temperature of $65^{\circ} \mathrm{C}$, the adiabatic temperature rise needs to be less than $35^{\circ} \mathrm{C}$ for starting materials that have an average temperature of $30^{\circ} \mathrm{C}\left(86^{\circ} \mathrm{F}\right)$. 


\subsection{Performance Assessment Hydraulic Property for Selected Mixes}

Saturated hydraulic conductivity was measured for select samples in the URS laboratory (ASTM D5084 Method C) and also at MACTEC, Atlanta GA. ${ }^{4}$ MACTEC used ASTM D5084 Method F and also characterized the moisture retention (drainage) as a function of saturation. MACTEC data sheets are provided in Attachment 1.

Table 3-5. Hydraulic properties for the grouts recommended for closing Tanks 18-F and 19-F.

\begin{tabular}{|c|c|c|c|c|c|c|c|c|c|}
\hline & $\begin{array}{c}\text { Saturated } \\
\text { Hydraulic } \\
\text { Conductivity } \\
\mathrm{K}_{\mathrm{s}} \text { at } 20^{\circ} \\
(\mathrm{cm} / \mathrm{s})\end{array}$ & $\begin{array}{c}\text { Saturated } \\
\text { Hydraulic } \\
\text { Conductivity } \\
\mathbf{K}_{\mathrm{s}} \text { at } 20^{\circ} \\
(\mathrm{cm} / \mathrm{s})\end{array}$ & $\begin{array}{c}\text { Saturated } \\
\text { Hydraulic } \\
\text { Conductivity } \\
\mathbf{K}_{\mathrm{s}} \text { at } 20^{\circ} \\
(\mathrm{cm} / \mathbf{y r}) \\
\end{array}$ & \begin{tabular}{|c|} 
Saturated \\
Effective \\
Diffusion \\
Coefficient \\
$\left(\mathrm{cm}^{2} / \mathrm{s}\right)$ \\
\end{tabular} & \begin{tabular}{|c||} 
Saturated \\
Effective \\
Diffusion \\
Coefficient, \\
$\mathrm{D}_{\mathrm{e}}\left(\mathrm{cm}^{2} / \mathrm{yr}\right)$ \\
\end{tabular} & $\begin{array}{c}\text { Effective } \\
\text { Porosity } \\
(\%) \\
\end{array}$ & $\begin{array}{c}\text { Dry Bulk } \\
\text { Density } \\
\left(\mathrm{g} / \mathrm{cm}^{3}\right) \\
\end{array}$ & $\begin{array}{l}\text { Average } \\
\text { Particle } \\
\text { Density } \\
\left(\mathrm{g} / \mathrm{cm}^{3}\right)\end{array}$ & $\begin{array}{c}\text { Moisture } \\
\text { Content } \\
\text { (Average) } \\
\text { (wt \%) }\end{array}$ \\
\hline Material & $\begin{array}{l}\text { URS } \\
\text { Method C }\end{array}$ & $\begin{array}{l}\text { MACTEC } \\
\text { Method F } \\
\end{array}$ & $\begin{array}{l}\text { MACTEC } \\
\text { Method F } \\
\end{array}$ & FTF PA & FTF PA & MACTEC & MACTEC & $\begin{array}{l}\text { Calcu- } \\
\text { lation }\end{array}$ & MACTEC \\
\hline LP\#8-16 & 2.1E-09 & $\begin{array}{c}\text { 3.1E-10 } \\
\text { average of } 3 \\
\text { samples }\end{array}$ & 9.78E-03 & $\begin{array}{r}5.0 \mathrm{E}-08 \\
\text { literature }\end{array}$ & $\begin{array}{r}1.58 \mathrm{E}+00 \\
\text { literature }\end{array}$ & 0.21 & 1.97 & 2.49 & 24.3 \\
\hline LP\#8-20 & $\begin{array}{c}\text { Not } \\
\text { Measured }\end{array}$ & $\begin{array}{c}\text { 3.5E-10 } \\
\text { average of } 3 \\
\text { samples }\end{array}$ & 1.10E-02 & $\begin{array}{r}5.0 \mathrm{E}-08 \\
\text { literature }\end{array}$ & $\begin{array}{r}1.58 \mathrm{E}+00 \\
\text { literature }\end{array}$ & 0.21 & 1.98 & 2.51 & 21.7 \\
\hline
\end{tabular}

Results for the moisture retention as a function of applied pressure (pressure plate test) are summarized in Table 3-6 for pressures between 0 and 15 bars. MACTEC data sheets are provided in Attachment 1. Samples were submitted to K. Dixon, SRNL, for moisture retention measurements over the range 15 to 45 bars but results are not available at this time. The intent is to combine both sets of results to calculate the relative hydraulic conductivity (hydraulic conductivity as a function of saturation) according to the protocol identified in SRNL-RP-2011-00977 [Stefanko and Langton, 2011]. The moisture retention data are reported as volumetric water content as a function of head pressure and are used as input to the RETC Code which is used to calculate relative hydraulic conductivity for input into the PORFLOW code. PORFLOW is the reactive transport code used for the FTF Performance Analysis.

Table 3-6. Moisture retention as a function of applied pressure for LP\#8-016 and LP\#8-020.

\begin{tabular}{|l|c|c|c|c|c|c|c|c|}
\hline & \multirow{2}{*}{$\begin{array}{c}\text { Initial } \\
\text { moisture } \\
\text { Sample No. }\end{array}$} & \multirow{2}{*}{$\begin{array}{c}\text { Dry unit } \\
\text { content }\end{array}$} & \multicolumn{5}{|c|}{ Applied Pressure (bars) } \\
\cline { 5 - 9 } & weight & $\mathbf{0 . 1 0}$ & $\mathbf{0 . 5 0}$ & $\mathbf{1 . 0}$ & \multicolumn{2}{|c|}{5.0} & $\mathbf{1 0 . 0}$ & $\mathbf{1 5 . 0}$ \\
\hline & (vol \%) & (lb/cft) & \multicolumn{6}{|c|}{ Retained Water (volume percent) } \\
\hline $\begin{array}{l}\text { LP\#8-016A } \\
\text { (average of 2) }\end{array}$ & 23.1 & 120.8 & 22.85 & 22.8 & 22.65 & 22.4 & 22.1 & 21.85 \\
\hline $\begin{array}{l}\text { LP\#8-020A } \\
\text { (average of 2) }\end{array}$ & 21.65 & 121.5 & 21.2 & 21.1 & 21.0 & 20.7 & 20.4 & 20.1 \\
\hline
\end{tabular}

\footnotetext{
${ }^{4}$ MACTEC was recently acquired by amec, Inc.
} 


\subsection{DISCUSSION}

The LP\#8 Series structural flowable fills with water to cementitious materials of 0.550 to 0.580 were down selected as candidates for filling Tanks 18-F and 19-F based on fresh properties, compressive strength at 28 days, and formulation robustness with respect to water and cement contents. The LP\#8 series of trial mixes were designed to be zero bleed, flowable structural fill grouts that contained 800 lbs/cyd of the 3/8 inch granite gravel. Benefits of including 3/8 inch pea gravel (No. 8 Stone) rather than using concrete sand as the only aggregate include: better mixing and homogeneity, better flows and compressive strengths as a function of water to cementitious material ratios.

\subsection{Compressive Strength}

All of the mixes in the LP\#8 series with water to cementitious materials ratios of 0.580 and 0.550 met the compressive strength requirement of 2000 psi at 28 days $^{5}$ identified in Technical Task Request HLETTR-2011-008 [Chander, 2011]. All of the mixes for which data has been collected exceed the requirement of 2000 psi by a factor of 2 (i.e., 4000 psi) after curing for 90 days. See Figures 4-1 and 4-2. 100 to 125 lbs of Portland cement and 210 pounds of Grade 100 ground granulated blast furnace slag are sufficient to meet the strength requirement.

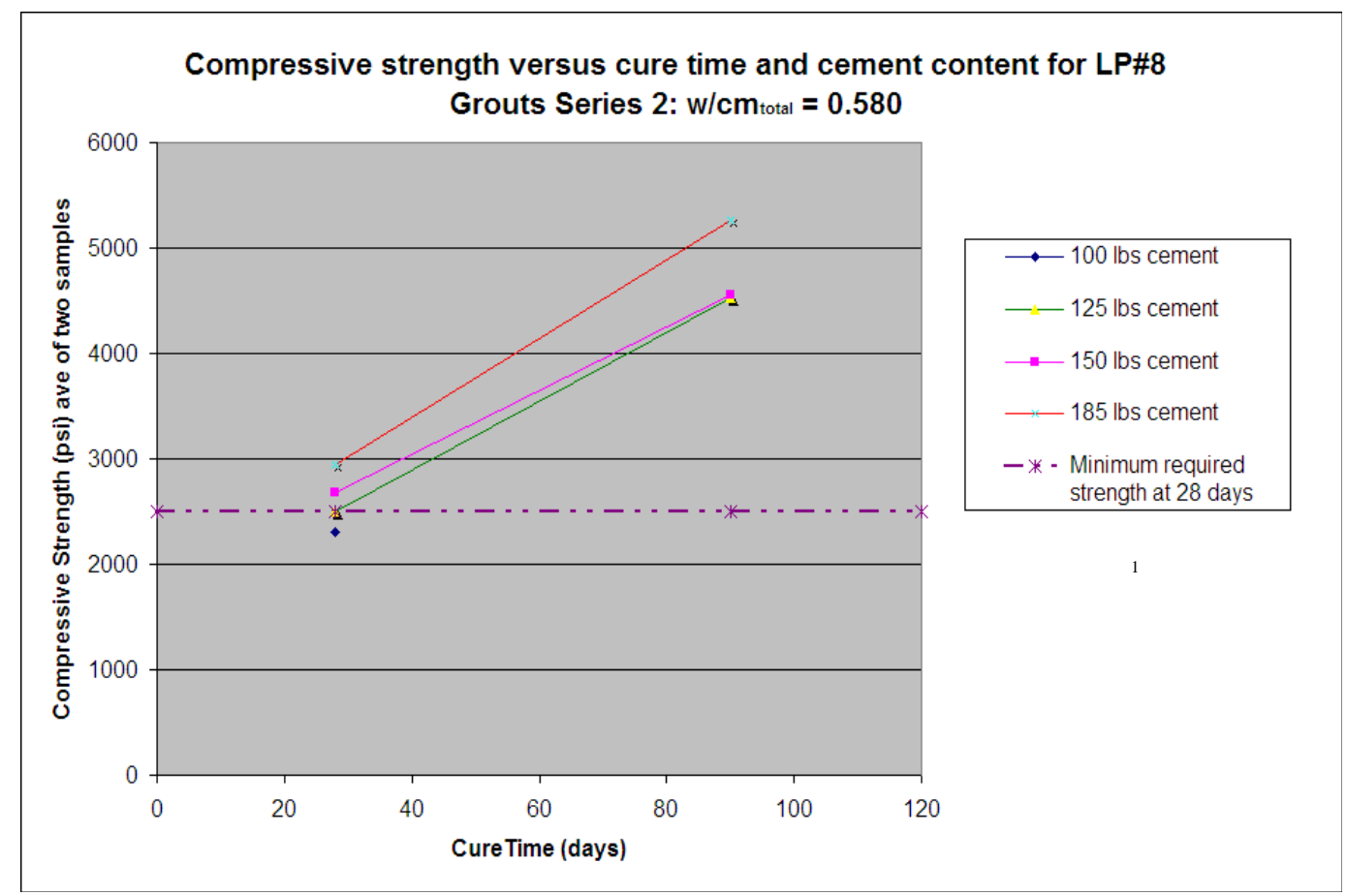

Figure 4-1. Compressive Strength versus cure time for LP\#8 Grout Series 2 mixes with different cement contents and water to cementitious material ratio of 0.580 .

\footnotetext{
${ }^{5}$ The basis for the 2000 psi at 28 days compressive strength requirement is the FTF PA. The functional basis of this compressive strength requirement is that the all-in-one grout must serve as an intruder barrier which requires a minimum strength of 2000 psi. The design requirement for compressive strength was 2500 psi to insure that the 2000 psi requirement is met for test cylinders evaluated during full-scale production. This assumes curing at $100 \%$ relative humidity, $73^{\circ} \pm 3^{\circ} \mathrm{F}$ [Langton, 2011].
} 


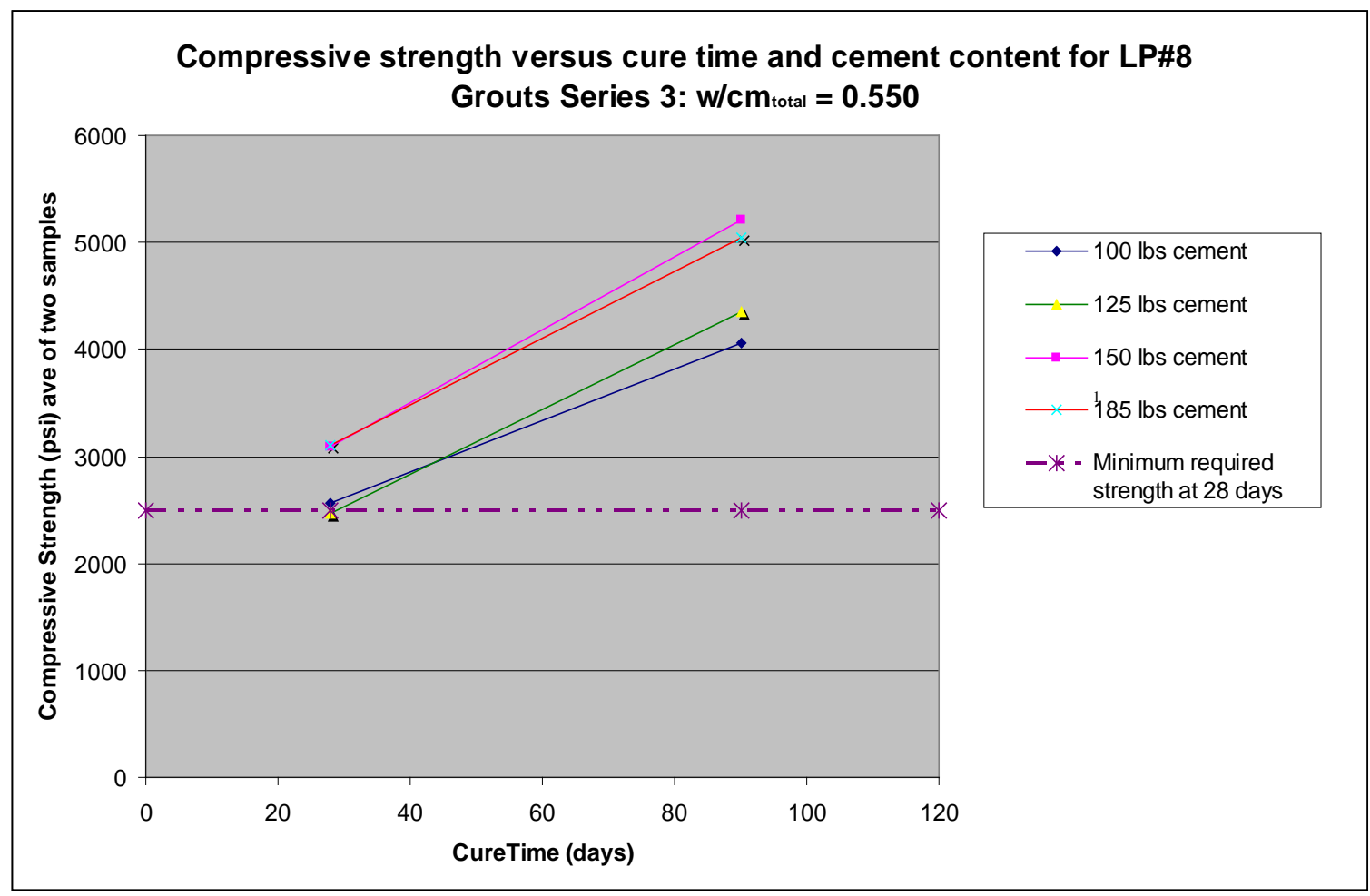

Figure 4-2. Compressive Strength versus cure time for LP\#8 Grout Series 2 mixes with different cement contents and water to cementitious material ratio of 0.550 .

\subsection{Heat of Hydration}

Further down selection was based on limited adiabatic temperature rise data and hydraulic conductivity data. Since limited adiabatic temperature rise data were available, information was compiled for all tank fill trial mixes tested. These results were compiled as a function of cementitious material proportions. The mixes had Portland cement contents between 75 and 185 pounds per cubic yard and slag contents of 210 and 260 pounds per cubic yard. Fly ash was not used in the comparison because the mixes do not have enough free calcium ion, i.e., $\mathrm{Ca}(\mathrm{OH})_{2}$ to react with all of the fly ash. The unreacted fly ash serves the function of an inert filler.

Mixes with $150 \mathrm{lbs} / \mathrm{cyd}$ cement and $260 \mathrm{lbs} / \mathrm{cyd}$ slag exceeded the maximum allowable temperature of $65^{\circ} \mathrm{C}$ as identified in the TTR for curing under adiabatic conditions [Chander, 2011]. Assuming an ambient temperature of $35^{\circ} \mathrm{C}\left(95^{\circ} \mathrm{F}\right)$, trial mixes with $150 \mathrm{lbs} / \mathrm{cyd}$ cement and $260 \mathrm{lbs} / \mathrm{cyd}$ exceed the requirement of $<65^{\circ} \mathrm{C}$, e.g., $37.2^{\circ} \mathrm{C}+35^{\circ} \mathrm{C}=72.2^{\circ} \mathrm{C}$. A trial mix containing $75 \mathrm{lbs} /$ cyd cement and 210 lbs/cyd met the requirement of $<65^{\circ} \mathrm{C}$, e.g., $27.2^{\circ} \mathrm{C}+35^{\circ} \mathrm{C}=62.2^{\circ} \mathrm{C}$.

It should be recognized that the tank fill conditions will not be truly adiabatic and that the calculated adiabatic temperature rise values presented in Table 4-1 assume complete reaction of 100 percent of the cement, slag, and fly ash. However, reducing the amount of cement and slag is justified because strength gain, i.e. hydration reactions are documented to occur over at least 90 days and result in more than doubling the strength measured for samples cured for 28 days. See Figure 4-1. 
Table 4-1. Adiabatic Temperature Rise Data for Selected Candidate Tank Fill Grout Trial Mixes.

\begin{tabular}{|l|c|c|c|c|c|c|c|c|}
\hline Mix Number & $\begin{array}{c}\text { Cement } \\
\text { (lb/cyd) }\end{array}$ & $\begin{array}{c}\text { Slag } \\
\text { (lb/cyd) }\end{array}$ & $\begin{array}{c}\text { Fly ash } \\
\mathbf{( l b / c y d )}\end{array}$ & $\begin{array}{c}\text { Run } \\
\text { Time } \\
\mathbf{( h r})\end{array}$ & $\begin{array}{c}\text { Start } \\
\mathbf{T e m p} \\
\left.\mathbf{(}{ }^{\circ} \mathbf{C}\right)\end{array}$ & $\begin{array}{c}\text { End } \\
\text { Temp } \\
\left.\mathbf{(}{ }^{\circ} \mathbf{C}\right)\end{array}$ & $\begin{array}{c}\text { Run } \\
\mathbf{\Delta T e m p} \\
\left({ }^{\circ} \mathbf{C}\right)\end{array}$ & $\begin{array}{c}\text { Calculated } \\
\text { Adiabatic } \\
\text { Temp Rise } \\
\left({ }^{\circ} \mathbf{C}\right)\end{array}$ \\
\hline FTF001H & 75 & 210 & 375 & 330 & 24 & 42.5 & 18.7 & 27.2 \\
\hline LP\#8-016 & 125 & 210 & 363 & $\begin{array}{c}\text { Not } \\
\text { measured }\end{array}$ & $\begin{array}{c}\text { Not } \\
\text { measured }\end{array}$ & $\begin{array}{c}\text { Not } \\
\text { measured }\end{array}$ & $\begin{array}{c}\text { Not } \\
\text { measured }\end{array}$ & $34^{*}$ \\
\hline LP\#8-020 & 125 & 210 & 363 & $\begin{array}{c}\text { Not } \\
\text { measured }\end{array}$ & $\begin{array}{c}\text { Not } \\
\text { measured }\end{array}$ & $\begin{array}{c}\text { Not } \\
\text { measured }\end{array}$ & $\begin{array}{c}\text { Not } \\
\text { measured }\end{array}$ & $34^{*}$ \\
\hline LP\#8-021 & 150 & 210 & 345 & 168 & 22 & 49.9 & 27.9 & 41.0 \\
\hline LP\#8-024 & 150 & 260 & 383 & 260 & 25 & 51.5 & 26.5 & 37.2 \\
\hline $\begin{array}{l}\text { FTF 70070 } \\
\text { mod 3H }\end{array}$ & 185 & 260 & 720 & 310 & 24 & 54 & 30.7 & 44.7 \\
\hline
\end{tabular}

* Estimated

The adiabatic calorimeter temperature rise for the mix recommended for closing Tank 18-F and 19-F was estimated rather measurements were not performed on the mix recommended for closing Tank 18-F and 19-F.

\subsection{Hydraulic Conductivity}

Further down selection was based on hydraulic conductivity values for selected mixes. Since limited data were available at the time this report was drafted, all information available for the LP\#8 Series mixes and related Reactor Fill Grout was compiled. All of the trial mixes tested met the saturated hydraulic conductivity requirement of $<3.6 \mathrm{E}-08 \mathrm{~cm} / \mathrm{s}$ for samples cured at least 44 days [Chander, 2011].

Saturated hydraulic conductivity results are presented in Table 4-2. The URS results were determined by ASTM D5084 Method C whereas the MACTEC results were determined by ASTM D5084 Method F. The lower pressure used in Method $\mathrm{C}$ produced less than values in the time of the measurement. Data provided by MACTEC are included in Attachment 1.

Table 4-2. Saturated Hydraulic Conductivities for Selected Candidate Tank Fill Grout Mixes.

\begin{tabular}{|c|c|c|c|c|c|c|c|}
\hline Mix Number & $\begin{array}{l}\text { Cement } \\
\text { (lb/cyd) }\end{array}$ & $\begin{array}{l}\text { Slag } \\
\text { (lb/cyd) }\end{array}$ & $\begin{array}{l}\text { Fly ash } \\
\text { (lb/cyd) }\end{array}$ & $\begin{array}{l}\text { Cure } \\
\text { Time } \\
\text { (days) }\end{array}$ & $\mathbf{W} / \mathbf{C M}_{\text {total }}$ & $\begin{array}{l}\text { URS } \\
\text { Hydraulic } \\
\text { Conductivity } \\
\mathrm{K}_{\mathrm{h} @ 20^{\circ} \mathrm{C}}(\mathrm{cm} / \mathrm{s})\end{array}$ & $\begin{array}{l}\text { MACTEC } \\
\text { Hydraulic } \\
\text { Conductivity } \\
\mathrm{K}_{\mathrm{h} @ 20^{\circ} \mathrm{C}}(\mathrm{cm} / \mathrm{s})\end{array}$ \\
\hline Reactor Fill Grout & 150 & 0 & 600 & $>180$ & 0.641 & $1.3 \mathrm{E}-08$ & Not measured \\
\hline LP\#8-016 & 125 & 210 & 363 & 70 & 0.580 & $2.1 \mathrm{E}-09$ & $3.1 \mathrm{E}-10$ \\
\hline LP\#8-020 & 125 & 210 & 363 & 70 & 0.550 & Not measured & $3.5 \mathrm{E}-10$ \\
\hline LP\#8-021 & 150 & 210 & 345 & 62 & 0.550 & 4.2E-09 & Not measured \\
\hline LP\#8-025 & 100 & 260 & 418 & 44 & 0.500 & $<2.10 \mathrm{E}-09$ & Not measured \\
\hline
\end{tabular}




\subsection{CONCLUSIONS AND RECOMMENDATIONS}

The cement and slag contents of the mix selected for filling Tanks 18-F and 19-F should be limited to no more than 125 and $210 \mathrm{lbs} / \mathrm{cyd}$, respectively, to account for heat generated as the result of hydration reaction during curing over extended times ( $>90$ days). Trial mixes with water to total cementitious materials ratios of 0.550 to 0.580 and 125 and $210 \mathrm{lbs} /$ cyd cement and slag, respectively, met the strength and permeability requirements.

Mix LP\#8-16 is recommended for scale-up testing to confirm suitability for the purpose of filling / closing Tanks 18-F and 19-F. ${ }^{6}$

Full-scale batching of the recommended mix should be performed in order to confirm scale-up in support of the procurement specification. The following items should be considered to validate the recommended mix:

- Batch at least 4 cubic yards of each material by a commercial batch plant and delivering the material to SRS. (4 cubic yards is about the minimum that can be batched and delivered in a 9 or 10 cubic yard concrete truck to provide a representative mixing and transport conditions.)

- Measure semi-adiabatic heat generation for a one cubic yard insulated pour.

- Evaluate fresh properties as a function of time (travel time and hold up time) after cement is added to the mixes.

- Evaluate cured properties.

- Evaluate flow properties of the grout at the batch plant and also at the point of delivery.

Mix LP\#8-16 is recommended for inclusion in the procurement specification for furnishing and delivering tank closure grout for Tanks 18-F and 19-F. The mix design is provided in Table 5-1.

Table 5-1. Tanks 18 and 19-F Bulk Fill Material Recommendation.

\begin{tabular}{|c|c|c|c|c|c|c|c|c|c|}
\hline $\begin{array}{c}\text { Mix } \\
\text { Number }\end{array}$ & $\begin{array}{c}\text { Cement } \\
\text { Type } \\
\text { I/II }\end{array}$ & $\begin{array}{c}\text { Slag } \\
\text { Grade } \\
100\end{array}$ & \begin{tabular}{|l} 
Fly Ash \\
Class F
\end{tabular} & $\begin{array}{c}\text { Type G } \\
\text { Shrinkage } \\
\text { Compensating } \\
\text { Component }\end{array}$ & $\begin{array}{c}\text { Sand } \\
\text { Quartz }\end{array}$ & $\begin{array}{c}\text { Gravel } \\
\text { No. } 8 \\
3 / 8 \text { in. }\end{array}$ & Water & $\begin{array}{c}\text { HRWR } \\
\text { SIKA Visco } \\
\text { Crete } 2100\end{array}$ & $\begin{array}{c}\text { VMA } \\
\text { Diutan Gum } \\
\text { Kelco-Crete DG }\end{array}$ \\
\hline & \multicolumn{6}{|c|}{ Lbs/cyd } & Gal / cyd & Fl oz / cyd & g / cyd \\
\hline LP\#8-16 & 125 & 210 & 363 & 0 & 1790 & 800 & 48.5 & 41 & 200 \\
\hline
\end{tabular}

Based on small scale laboratory flow test results and knowledge of flow of this type of grout in the recent SRS reactor facility In-Situ Decommissioning Projects, the recommended grout is expected to flow at least 45 feet. A single point of discharge should be sufficient for unrestricted flow conditions. However, additional entry points should be identified as back up in case restrictions in the tank impede flow.

The Procurement Specification for the tank fill grout allows the Subcontract Technical Representative (STR) to use discretion with respect to accepting mixes that exceed the delivery temperature limit of $90^{\circ} \mathrm{F}$. Since the tank curing conditions are semi adiabatic (lower than adiabatic), Material acceptance should be based on the delivery temperature.

The final recommendation is to complete the FY11 scope as outlined in Section 6.0.

\footnotetext{
6 A shrinkage compensating variation of this mix was being evaluated but further development and testing was postponed at the direction of SRR. The shrinkage compensating ingredient in the CompCon ${ }^{\circledR}$ component is $\mathrm{CaO}$ which hydrates to $\mathrm{Ca}(\mathrm{OH})_{2}$ and has an added benefit of providing additional buffering capacity at a pH of 12.4.
} 


\subsection{FUTURE WORK}

1. Complete hydraulic property testing for the recommended non shrinkage compensating mixes is recommended. This scope includes:

- Complete characterization of moisture retention for Mixes LP\#8-016 and Mixes LP\#8-020 in the range of 15 to 45 bars and merge the 0 to 15 and 15 to 45 bar data to generate van Genuchten parameters and relative hydraulic conductivities for input to the PORFLOW code used in the FTF PA.

o Samples were prepared, cured, and turned over to K. Dixon, SRNL for testing which is tentatively scheduled to begin in FY12.

2. Initiate SIMCO Moisture Test and Drying Test to obtain material specific effective diffusivities, tortuosities and saturated and unsaturated hydraulic conductivities using methods with lower detection limits than those used to obtain data presented in this report. Refer to the tank fill requirements document for details [Stefanko and Langton, 2011].

- $\quad$ Prepare SOW and award contract to SIMCO Technologies to characterize Mixes LP\#8- 016 and Mixes LP\#8-020 samples using the SIMCO Moisture Test and Drying Test. (SRNL)

- Analyze and report results. (SRNL)

3. Complete FY11 Scope. During August, 2011, a portion of the scope identified in HLE-TTR-2011008 was postponed until FY12. This scope should be completed to address mitigation of the inherent potential for fast pathways and includes:

- Final development and testing of shrinkage compensating tank fill all-in-one mix design.

o Fresh property testing

o Cured property testing

- Saturated and unsaturated hydraulic properties (MACTEC/amec and SIMCO)

- Adiabatic temperature rise (SRNL)

- Shrinkage as a function of time, temperature, and humidity (drying) (SRNL)

4. Summarize results of the tank fill scale-up test.

- Compile compressive strength results for samples cured for up to 90 days.

- Summarize semi adiabatic temperature rise results from the one cubic foot form poured in FArea and compare results to adiabatic temperature rise data.

- $\quad$ Prepare report on the tank fill scale-up test.

5. Support procurement of the tank fill grout and bidder evaluation and mix qualification.

6. Provide support to Closure Project Engineering and Operations as requested to close Tanks 18-F and 19-F. 


\subsection{REFERENCES}

ACI 237R-07, 2007. “Self-Consolidating Concrete,” Report by ACI Committee 237, May 2007, Emerging Technology Series, American Concrete Institute, Farmington Hills, MI 48331.

ACI 223-98, 2009. “Standard Practice for Shrinkage Compensating Concrete,” American Concrete Institute, Farmington Hills, MI 48331.

Chander, V. A., 2011. “Develop Tank Closure Technology Grout Formulations for Tank(s) 18 \&19,” HLE-TTR-2011-008, March 10, 2011, Savannah River Remediation, Aiken, SC, 29808.

Dixon, K. and M. Phifer, 2007. "Hydraulic and Physical Properties of Tank Grouts and Base Mat Surrogate Concrete for FTF Closure,” WSRC-STI-2007-00369, Revision 0, Washington Savannah River Company, Aiken SC 29808.

Forty, R. W. and A. Ganguly, 2011a. Procurement Specification for Furnishing and Delivery of Tank Closure Grout, C-SPP-F-00055, Revision 0, Savannah River Remediation Savannah River Site, Aiken, SC 29808.

Forty, R. W. and A. Ganguly, 2011b. Procurement Specification for Furnishing and Delivery of Tank Closure Grout, C-SPP-F-00055, Revision 1, Savannah River Remediation Savannah River Site, Aiken, SC 29808.

Forty, R. W. and A. Ganguly, 2011c. Procurement Specification for Furnishing and Delivery of Tank Closure Grout, C-SPP-F-00055, Revision 2, Savannah River Remediation Savannah River Site, Aiken, SC 29808.

Guerrero, H. N. and M. L. Restivo, 2011. “Testing and Analysis of Cap Concrete Stress and Strain Due to Shrinkage,Creep, and Expansion - Final Report, SRNL-STI-2010-00771, August, 2011, Savannah River National Laboratory, Savannah River Site, Aiken, SC, 29808.

Hyche, J. P., 2011. Personal Communication at Tank Grouting Project Meeting, July 2011, Savannah River Remediation, Aiken, SC, 29808.

Jolly, R. C., Jr., 2011. Personal Communication with H. H. Burns (SRNL) August 2011, Savannah River Remediation, Aiken, SC, 29808.

Langton, C. A., 2007. "Chemical Degradation Assessment of Cementitious Materials for the HLW Tank Closure Project (U), WSRC-STI-2007-0067 Revision 0., September 14, 2007, Washington Savannah River Company, Aiken SC 29808.

Langton, C. A. and N. Rajendran, 1998. "Laboratory and Field Testing of High Performance Zero Bleed CLSM Mixes for Future Tank Closure Applications (U), WSRC-TR-98-271 Revision 0, March 30, 1998, Westinghouse Savannah River Company, Aiken, SC 29808.

Langton, C. A., R. D. Spence and J. Barton, 2001. "State of the Art Report on High-Level Waste Tank Closure (U)”, WSRC-TR-2001-00359, Revision 0, July 31, 2001, Westinghouse Savannah River Company, Aiken, SC 29808. 
Langton, C. A. and D. B. Stefanko, 2011. "Bulk Fill Grout Recommendations for Tanks 18-F and 19F,” SRNL-L3100-2011-00180, August 31, 2011, Savannah River National Laboratory, Savannah River Site, Aiken, SC, 29808.

Langton, C. A. and J. T. Waymer, 2010. “R-Reactor Disassembly Basin Fill Materials,” SRNL-STI2010-00426, July 26, 2010, Savannah River National Laboratory, Aiken, SC, 29808.

Langton, C. A., A. Ganguly, C. A. Bookhamer, M. Koval, and W. L. Mhyre, 2007. "Grout Formulations and Properties for Tank Farm Closure (U),” WSRC-STI-2007-00641 Revision 0, November 12, 2007, Washington Savannah River Company, Savannah River National Laboratory, Aiken, SC 29808.

Langton, C. A., 2011. Personal Communication at Tank Grouting Project Meeting, June, 2011, Savannah River National Laboratory, Aiken, SC, 29808.

Newman, J. L., 2006. “Analysis of Grout and Base Mat Samples: Development of Alternative Grout Samples for Tank Closure - Technical Task Request,” PIT-TTR-2006-00002, December 1, 2006, Washington Savannah River Company, Aiken SC 29808.

SRS, 2007. Performance Assessment for F-Tank Farm at Savannah River Site, Savannah River Site, SRS-REG-2007-00002, Rev. 1, March 31, 2010, Aiken, SC, 29808.

SRR Closure Module, 2011. “ Industrial Wastewater Closure Module for the Liquid Waste Tanks 18 and 19 F-Area Tank Farm, Savannah River Site,” SRR-CWDA-2010-00003, Revision 0, Savannah River Remediation Closure and Waste Authority, Aiken, SC, 29808.

C-SPP-F-00047, Revision 2, 2003. "Tank Farm: Tank 18F and Tank 19F, Furnishing and Delivery of Tank Closure Mixes (U),” March 2, 2003, Washington Savannah River Company, Aiken SC 29808.

Stefanko, D. B., Guerrero, H. N., Reigel, M. M., and C. A. Langton, 2011. “Task Technical and Quality Assurance Plan for Developing and Testing Grout Formulations for Filling Tanks 18-F and 19-F and Abandoned Equipment," SRNL-RP-2011-00587, Revision 0, March 22, 2011, Savannah River National Laboratory, Savannah River Site, Aiken, SC, 29808.

Stefanko D. B. and C. A. Langton, 2011. “Tank 18 and 19-F Grout Fill Engineering Requirements,” SRNL-RP-2011-00977, August 2011, Savannah River National Laboratory, Savannah River Site, Aiken, SC, 29808.

Steimke, J. L. and M. D. Fowley, "Measurement of Thermal Properties of Saltstone", WSRC-TR-9700357, May 1998, Westinghouse Savannah River Company, Savannah River Site, Aiken, SC, 29808.

Waymer, J. T. 2011. E-mail to D. Stefanko and C. Langton, "Particle size distributions,” October 3, 2011. URS Washington Division, Savannah River Site, Aiken, SC, 29808. 


\section{Attachment 1. MACTEC TEST REPORT}

Insert MACTEC report once file is converted to pdf. 
October 20, 2011

Savannah River Nuclear Solutions

Bldg. 730-4B Room 3016

Aiken, SC 29808

Attention: $\quad$ Mr. Bill Joyce, STR

Subject: $\quad$ Revised Test Report - F-Area Tank Farm Grout Samples

Subcontract No. AC54317N, Delivery Order No. 25

Specification K-SPC-G-00013, Rev. 12

MACTEC Project No. 6155-08-0031

Dear Mr. Joyce:

MACTEC Engineering \& Consulting, Inc. (MACTEC) has completed the assigned testing services for Delivery Order No. 25, Subcontract No. AC54317N. The test results are included in Attachment 1. An equipment list used in this Delivery Order is included in Attachment 2. The tests performed in this Delivery Order are listed below along with applicable ASTM or other procedures:

$\begin{array}{ll}\text { Capillary/Moisture Relationship } & \text { ASTM D3152 } \\ \text { Unit Weight and Moisture Content } & \text { TP-4 } \\ \text { Permeability } & \text { ASTM D5084 }\end{array}$

These tests were performed in accordance with the above referenced contract order and MACTEC's Quality Assurance Manual (QAM) Revision 1.

A report dated October 4, 2011 was previously issued. An error was later discovered. This report supersedes the previous one dated October 4, 2011.

We appreciate the opportunity of serving your geotechnical laboratory testing needs. If you have questions, please contact us.

Sincerely,

MACTTE Engineering and Consulting, Inc.
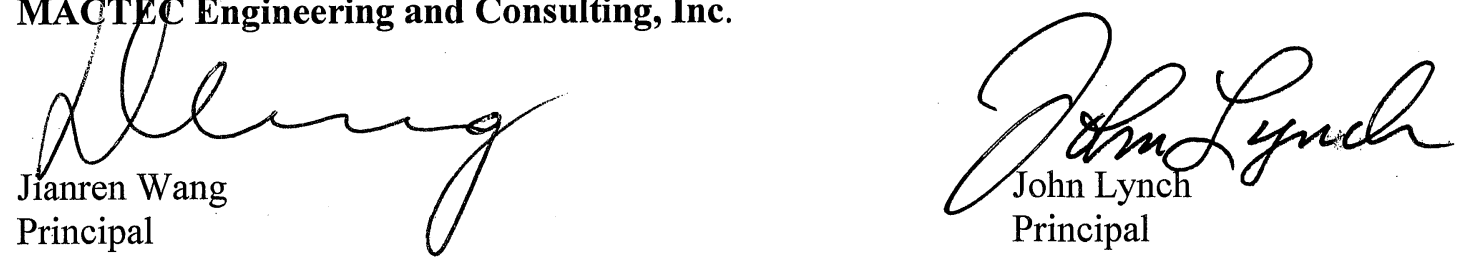

$$
\begin{array}{ll}
\text { Cc: } & \text { SRNS } \\
& \text { Vendor Documents } \\
& \text { Building 704-IN/Room } 137 \\
& \text { Aiken, SC 29808 }
\end{array}
$$




\section{HYDRAULIC CONDUCTIVITY}

\begin{tabular}{|c|c|c|c|}
\hline Project No. & $6155-08-0031.25$ & Tested By & $J W$ \\
\hline Project Name & \multicolumn{2}{|c|}{ F-Area Tank Farm Grout Sampl Test Date } & $9 / 2 / 2011$ \\
\hline Boring No. & $L P \# 8-016 A$ & Reviewed By & $g \varepsilon f$ \\
\hline Sample No. & $L P \# 8-016 A$ & Review Date & $10 / 4 / 11$ \\
\hline Sample Depth & $N / A$ & Lab No. & 11003 \\
\hline
\end{tabular}

Sample Description Grout

ASTM D5084 - Method F (CVFH)

\begin{tabular}{|l|l|}
\hline Sample Type: & Core \\
\hline Sample Orientation: & Vertical \\
\hline Initial Water Content, \%: & 11.3 \\
\hline Wet Unit Weight, pcf: & 136.5 \\
\hline Dry Unit Weight, pcf: & 122.6 \\
\hline Compaction, \%: & N/A \\
\hline Hydraulic Conductivity, cm/sec. @20 ${ }^{\circ} \mathrm{C}$ & $3.1 E-10$ \\
\hline
\end{tabular}

Remarks: 


\section{(ASTM D5084 - 03) (Method F, Constant Volume Falling Head)}

Project Number 6155-08-0031.25

Tested By JW

Project Name F-Area Tank Farm Grout Sample Test Date 09/02/11

Boring No. LP\#8-016A Reviewed By J\&f

Sample No. LP\#8-016A Review Date 10/4/11

Sample Depth N/A Lab No. 11003

Sample Description Grout

\begin{tabular}{|c|r|c|r|c|r|}
\hline \multicolumn{4}{|c|}{ Initial Sample Data } & \multicolumn{2}{c|}{ Final Sample Data } \\
\hline \multicolumn{2}{|c|}{ Length, in } & \multicolumn{2}{c|}{ Diameter, in } & Pan No. & \multicolumn{1}{c|}{ N/A } \\
\hline Location 1 & 4.022 & Location 1 & 3.014 & Wet Soil+Pan, grams & 1039.79 \\
\hline Location 2 & 4.043 & Location 2 & 3.019 & Dry Soil + Pan, grams & 933.42 \\
\hline Location3 & 4.108 & Location 3 & 3.016 & Pan Weight, grams & 0 \\
\hline Average & 4.058 & Average & 3.016 & Moisture Content, \% & 11.4 \\
\hline Volume, in & 29.00 & Wet Soil + Tare, grams & 1039.25 & Dry Unit Weight, pcf & 122.6 \\
\hline SG Assumed & 2.50 & Tare Weight, grams & 0.00 & Saturation, \% & 104.7 \\
\hline Soil Sample Wt., g & 1039.25 & Dry Soil +Tare, grams & 933.42 & Diameter, in. & N/A \\
\hline Dry UW, pcf & 122.6 & Moisture Content, \% & 11.3 & Length, in. & N/A \\
\hline Saturation, \% & 104.2 & & & Volume, in & N/A \\
\hline
\end{tabular}

\begin{tabular}{|r|c|c|c|r|r|r|r|r|r|}
\hline $\begin{array}{c}\text { Elapsed Time } \\
(\mathrm{sec})\end{array}$ & $\begin{array}{c}\mathrm{z}_{\mathrm{o}} \\
(\mathrm{cm})\end{array}$ & $\begin{array}{c}\mathrm{za} \\
(\mathrm{cm})\end{array}$ & $\begin{array}{c}\mathrm{zb} \\
(\mathrm{cm})\end{array}$ & $\begin{array}{c}\Delta \mathrm{z}_{\mathrm{p}} \\
(\mathrm{cm})\end{array}$ & $\begin{array}{c}\text { Temp } \\
\left({ }^{\circ} \mathrm{C}\right)\end{array}$ & $\begin{array}{c}\text { Intial } \\
\text { Hydraulic } \\
\text { Gradient }\end{array}$ & $\begin{array}{c}\text { Final } \\
\text { Hydraulic } \\
\text { Gradient }\end{array}$ & $\begin{array}{c}\mathrm{k} \\
\mathrm{cm} / \mathrm{sec} \\
\mathrm{cm} / \mathrm{sec} \\
\mathrm{at} 2{ }^{\circ} \mathrm{C}\end{array}$ \\
\hline 13080 & 1.70 & 28.20 & 27.80 & 0.40 & 23.3 & 32.3 & 31.8 & $6.50 \mathrm{E}-10$ & $6.01 \mathrm{E}-10$ \\
\hline 19380 & 1.70 & 28.20 & 27.70 & 0.50 & 23.3 & 32.3 & 31.7 & $5.49 \mathrm{E}-10$ & $5.08 \mathrm{E}-10$ \\
\hline 82620 & 1.70 & 28.20 & 27.20 & 1.00 & 23.2 & 32.3 & 31.1 & $2.60 \mathrm{E}-10$ & $2.41 \mathrm{E}-10$ \\
\hline 104280 & 1.70 & 28.20 & 27.00 & 1.20 & 23.5 & 32.3 & 30.8 & $2.49 \mathrm{E}-10$ & $2.29 \mathrm{E}-10$ \\
\hline 166320 & 1.70 & 28.20 & 26.60 & 1.60 & 23.1 & 32.3 & 30.3 & $2.09 \mathrm{E}-10$ & $1.95 \mathrm{E}-10$ \\
\hline 188400 & 1.70 & 28.20 & 26.40 & 1.80 & 23.3 & 32.3 & 30.0 & $2.09 \mathrm{E}-10$ & $1.93 \mathrm{E}-10$ \\
\hline 251520 & 1.70 & 28.20 & 26.00 & 2.20 & 23.2 & 32.3 & 29.5 & $1.93 \mathrm{E}-10$ & $1.79 \mathrm{E}-10$ \\
\hline
\end{tabular}

\begin{tabular}{|c|c|c|c|c|}
\hline No. of Trials & $\begin{array}{c}\text { Sample } \\
\text { Type }\end{array}$ & $\begin{array}{c}\text { Max. Density } \\
(\mathrm{pcf})\end{array}$ & $\begin{array}{c}\text { Compaction } \\
\%\end{array}$ & $\begin{array}{c}\text { Sample } \\
\text { Orientation }\end{array}$ \\
\hline 7 & Core & N/A & N/A & Vertical \\
\hline
\end{tabular}

Avg. $\mathrm{k}$ at $20^{\circ} \mathrm{C} \quad 3.1 \mathrm{E}-10 \mathrm{~cm} / \mathrm{sec}$

$$
\begin{aligned}
\mathrm{a}_{\mathrm{a}} & =\frac{0.76712 \mathrm{~cm}^{2}}{46.10} \mathrm{~cm}^{2} \\
\mathrm{~A} & =\frac{10.31 \mathrm{~cm}}{\mathrm{~L}}=\frac{}{0.22356} \mathrm{1} / \mathrm{cm}
\end{aligned}
$$

$$
\begin{array}{rc}
\mathrm{a}_{\mathrm{p}}= & 0.031416 \mathrm{~cm}^{2} \\
\mathrm{M}_{1}= & 0.03018 \\
\mathrm{M}_{2}= & 1.04095 \\
\mathrm{C}=\mathrm{M}_{1} \mathrm{~S} /\left(\mathrm{G}_{\mathrm{Hg}}-1\right)= & 0.0005368 \text { for } 15^{\circ} \text { to } 25^{\circ} \\
& \text { SRS175 Page } 4 \text { of } 12
\end{array}
$$

Remarks:

Chamber Pressure, psi 60

Back Pressure, psi

Confining Pressure, psi

Initial Burett Reading

Final Burett Reading

Volume Change, cc

Permeant used 


\section{HYDRAULIC CONDUCTIVITY}

\begin{tabular}{|c|c|c|c|}
\hline Project No. & $6155-08-0031.25$ & Tested By & $J W$ \\
\hline Project Name & F-Area Tank Farm Grout Samp & I.Test Date & $9 / 2 / 2011$ \\
\hline Boring No. & $L P \# 8-020 A$ & Reviewed By & $g \varepsilon d$ \\
\hline Sample No. & $L P \# 8-020 A$ & Review Date & $10 / 4 / 11$ \\
\hline Sample Depth & $N / A$ & Lab No. & 11004 \\
\hline
\end{tabular}

Sample Description Grout

ASTM D5084 - Method F (CVFH)

\begin{tabular}{|l|l|}
\hline Sample Type: & Core \\
\hline Sample Orientation: & Vertical \\
\hline Initial Water Content, \%: & 11.1 \\
\hline Wet Unit Weight, pcf: & 136.9 \\
\hline Dry Unit Weight, pcf: & 123.2 \\
\hline Compaction, \%: & N/A \\
\hline Hydraulic Conductivity, cm/sec. @20 ${ }^{\circ} \mathrm{C}$ & $3.5 E-10$ \\
\hline
\end{tabular}

Remarks: 
Project Number 6155-08-0031.25

Tested By JW

Project Name F-Area Tank Farm Grout Sample Test Date 09/02/11

Boring No. LP\#8-020A Reviewed By JGJ

Sample No. LP\#8-020A Review Date 10/4/11

Sample Depth N/A Lab No. 11004

Sample Description Grout

\begin{tabular}{|c|r|c|r|c|r|}
\hline \multicolumn{4}{|c|}{ Initial Sample Data } & \multicolumn{2}{c|}{ Final Sample Data } \\
\hline \multicolumn{2}{|c|}{ Length, in } & \multicolumn{2}{c|}{ Diameter, in } & Pan No. & \multicolumn{1}{c|}{ N/A } \\
\hline Location 1 & 3.036 & Location 1 & 3.013 & Wet Soil+Pan, grams & 773.12 \\
\hline Location 2 & 3.022 & Location 2 & 3.011 & Dry Soil + Pan, grams & 695.29 \\
\hline Location3 & 2.986 & Location 3 & 3.017 & Pan Weight, grams & 0 \\
\hline Average & 3.015 & Average & 3.014 & Moisture Content, \% & 11.2 \\
\hline Volume, in & 21.50 & Wet Soil + Tare, grams & 772.53 & Dry Unit Weight, pcf & 123.2 \\
\hline SG Assumed & 2.50 & Tare Weight, grams & 0.00 & Saturation, \% & 105.0 \\
\hline Soil Sample Wt., g & 772.53 & Dry Soil + Tare, grams & 695.29 & Diameter, in. & N/A \\
\hline Dry UW, pcf & 123.2 & Moisture Content, \% & 11.1 & Length, in. & N/A \\
\hline Saturation, \% & 104.2 & & & Volume, in & N/A \\
\hline
\end{tabular}

\begin{tabular}{|r|r|r|r|r|r|r|r|r|r|}
\hline $\begin{array}{c}\text { Elapsed Time } \\
(\mathrm{sec})\end{array}$ & $\begin{array}{c}\mathrm{z}_{\mathrm{o}} \\
(\mathrm{cm})\end{array}$ & $\begin{array}{c}\mathrm{za} \\
(\mathrm{cm})\end{array}$ & $\begin{array}{c}\mathrm{zb} \\
(\mathrm{cm})\end{array}$ & $\begin{array}{c}\Delta \mathrm{z}_{\mathrm{p}} \\
(\mathrm{cm})\end{array}$ & $\begin{array}{c}\text { Temp } \\
\left({ }^{\circ} \mathrm{C}\right)\end{array}$ & $\begin{array}{c}\text { Intial } \\
\text { Hydraulic } \\
\text { Gradient }\end{array}$ & $\begin{array}{c}\text { Final } \\
\text { Hydraulic } \\
\text { Gradient }\end{array}$ & $\begin{array}{c}\mathrm{k} \\
\mathrm{cm} / \mathrm{sec}\end{array}$ & $\begin{array}{c}\mathrm{k} \\
\mathrm{cm} / \mathrm{sec} \\
\mathrm{at} 2{ }^{\circ} \mathrm{C}\end{array}$ \\
\hline 83580 & 1.70 & 27.10 & 25.20 & 1.90 & 23.4 & 41.7 & 38.4 & $3.87 \mathrm{E}-10$ & $3.57 \mathrm{E}-10$ \\
\hline 98700 & 1.70 & 27.10 & 24.90 & 2.20 & 23.7 & 41.7 & 37.9 & $3.82 \mathrm{E}-10$ & $3.50 \mathrm{E}-10$ \\
\hline 110340 & 1.70 & 27.10 & 24.80 & 2.30 & 23.4 & 41.7 & 37.8 & $3.58 \mathrm{E}-10$ & $3.31 \mathrm{E}-10$ \\
\hline 344160 & 1.70 & 27.10 & 20.80 & 6.30 & 22.8 & 41.7 & 30.9 & $3.47 \mathrm{E}-10$ & $3.24 \mathrm{E}-10$ \\
\hline 8100 & 1.70 & 26.90 & 26.70 & 0.20 & 23.3 & 41.4 & 41.0 & $4.09 \mathrm{E}-10$ & $3.78 \mathrm{E}-10$ \\
\hline 17200 & 1.70 & 26.90 & 26.50 & 0.40 & 23.3 & 41.4 & 40.7 & $3.87 \mathrm{E}-10$ & $3.58 \mathrm{E}-10$ \\
\hline 43170 & 1.70 & 26.90 & 25.90 & 1.00 & 23.1 & 41.4 & 39.7 & $3.90 \mathrm{E}-10$ & $3.63 \mathrm{E}-10$ \\
\hline
\end{tabular}

\begin{tabular}{|c|c|c|c|c|}
\hline No. of Trials & $\begin{array}{c}\text { Sample } \\
\text { Type }\end{array}$ & $\begin{array}{c}\text { Max. Density } \\
\text { (pcf) }\end{array}$ & $\begin{array}{c}\text { Compaction } \\
\%\end{array}$ & $\begin{array}{c}\text { Sample } \\
\text { Orientation }\end{array}$ \\
\hline 7 & Core & N/A & N/A & Vertical \\
\hline
\end{tabular}

Avg. $\mathrm{k}$ at $20^{\circ} \mathrm{C} \quad 3.5 \mathrm{E}-10 \mathrm{~cm} / \mathrm{sec}$

$$
\begin{aligned}
\mathrm{a}_{\mathrm{a}} & =\frac{0.76712 \mathrm{~cm}^{2}}{\mathrm{~A}}=\frac{46.02}{\mathrm{~cm}^{2}} \\
\mathrm{~L} & =\frac{7.66}{\mathrm{~cm}} \\
\mathrm{~S}=\mathrm{L} / \mathrm{A} & =\frac{0.16639}{1 / \mathrm{cm}}
\end{aligned}
$$

$$
\begin{aligned}
& \mathrm{a}_{\mathrm{p}}=0.031416 \mathrm{~cm}^{2} \\
& \mathrm{M}_{1}=0.03018 \\
& \mathrm{M}_{2}=1.04095 \\
& \mathrm{C}=\mathrm{M}_{1} \mathrm{~S} /\left(\mathrm{G}_{\mathrm{Hg}}-1\right)=0.0003995 \text { for } 15^{\circ} \text { to } 25^{\circ} \\
& \text { SRS175 Page } 6 \text { of } 12
\end{aligned}
$$

Remarks:

\begin{tabular}{ll}
\multicolumn{2}{c}{ Consolidation } \\
\hline Chamber Pressure, psi & \multicolumn{6}{c}{60} \\
Back Pressure, psi & 50 \\
Confining Pressure, psi & 10 \\
Initial Burett Reading & 0 \\
Final Burett Reading & 0 \\
Volume Change, cc & $\underline{0}$
\end{tabular}

Permeant used water 


\section{Water Retention Test \\ (ASTM D3152-72 (1994))}

$\begin{array}{llll}\begin{array}{l}\text { Project No } \\ \text { Tested By } \\ \text { Reviewed By }\end{array} & \frac{6155-08-0031.25}{\mathrm{JW}} & \begin{array}{l}\text { Project Name } \\ \text { Test Date } \\ \text { Review Date }\end{array} & \begin{array}{l}\frac{\text { F-area Tank Farm Grout Samples }}{9 / 9 / 11-10 / 4 / 11} \\ \text { 10/20/11 }\end{array}\end{array}$

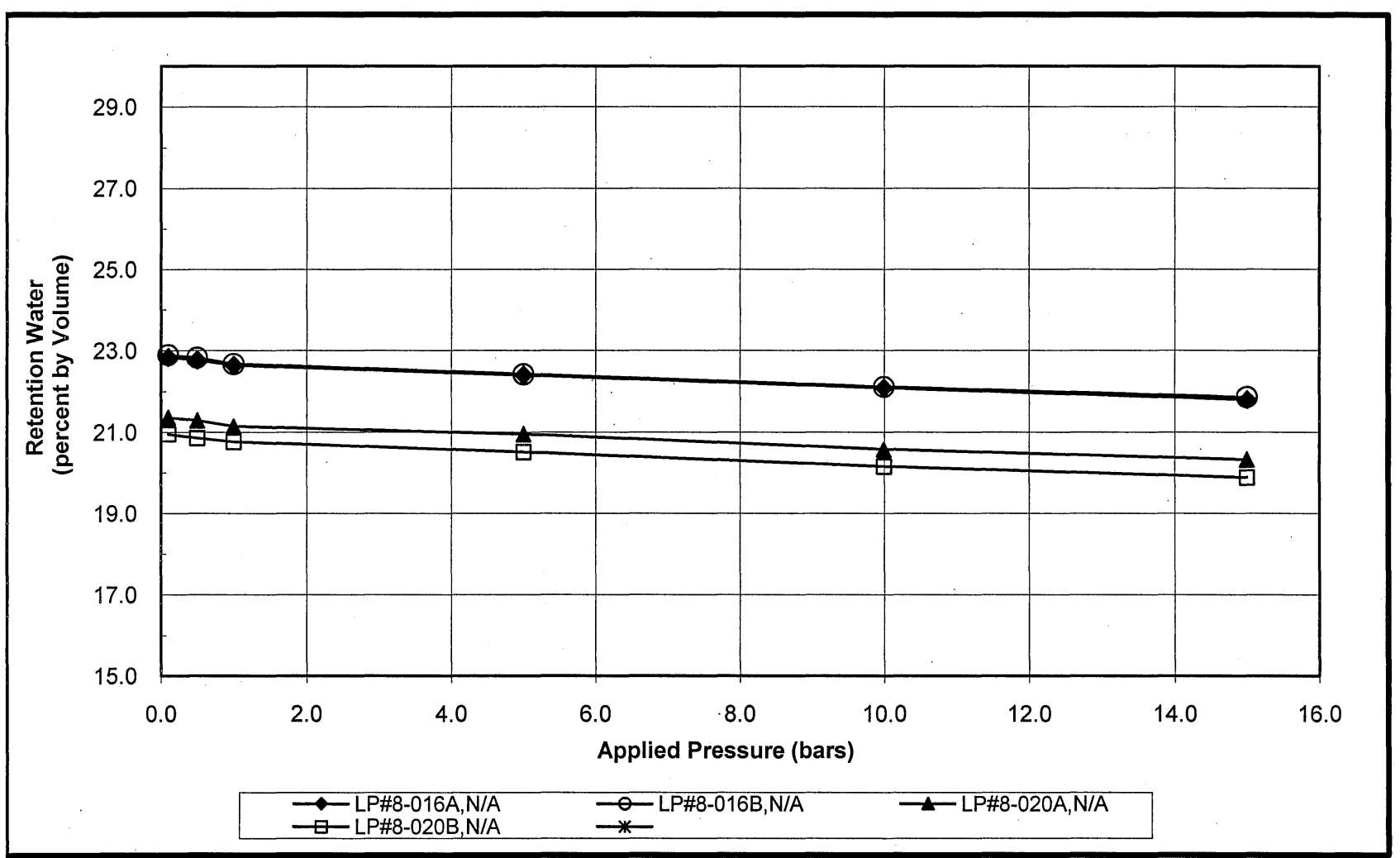

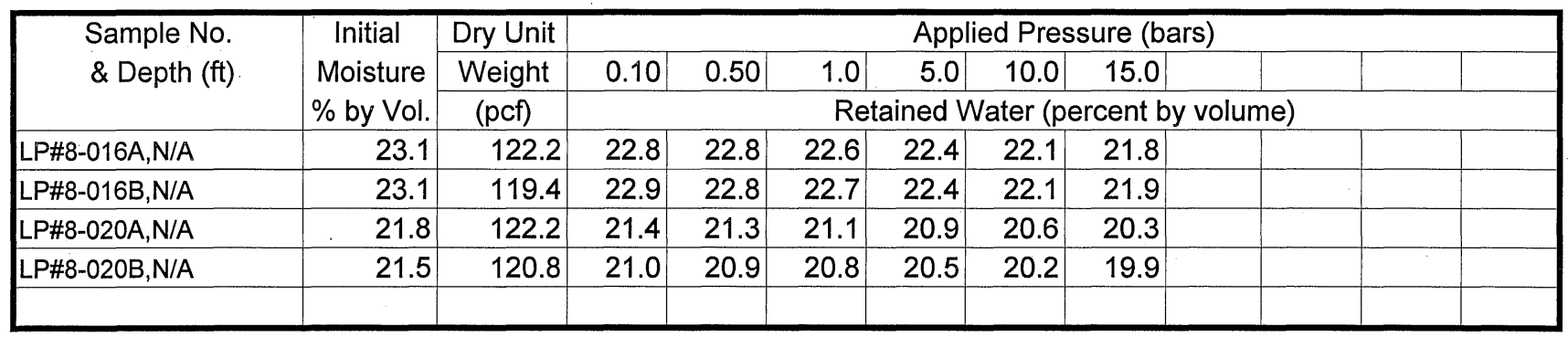

Remarks: The effective porosity (effective drainage porosity as defined by ASTM D653, as a percent, is found for an applied pressure by subtracting the retained percent water (by volume) from the saturation percent water.

When testing at pressures higher than one bar, ASTM D2325 using similar equipment designed for the required capacity.

Revised Report 
Water Retention Test

(ASTM D3152-72 (1994))

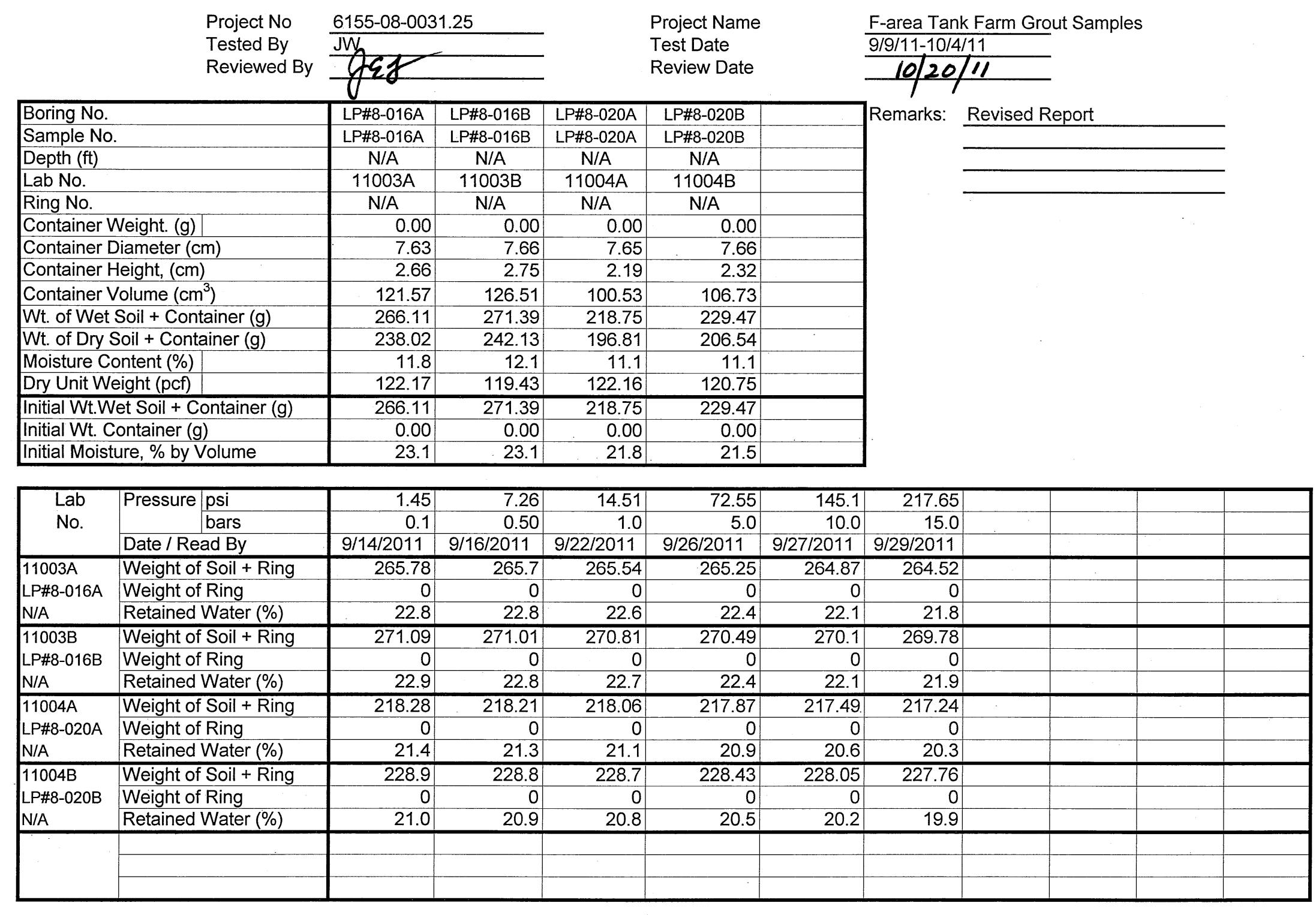

No. of Samples

No. of Tests per Sample 


\section{MACTEC}

\section{TP-4 UNIT WEIGHT OF SAMPLE}

Project No.: 6155-08-0031.25

Project Name: F-Area Tank Farm Grout Samples Lab No. 11003

Tested By: $\mathrm{EH}$

Date: 09/02/11
Boring No.: LP\#8-016A

Sample No.: LP\#8-016A

Depth: N/A

Reviewed By: JW

Date: 09/26/11

\begin{tabular}{|c|c|c|c|c|c|c|}
\hline \multicolumn{2}{|c|}{$\begin{array}{l}\text { Total Sample } \\
\text { Height, inches }\end{array}$} & \multicolumn{2}{|c|}{$\begin{array}{c}\text { Inside Diameter } \\
\text { of Cut Tube, inches }\end{array}$} & \multicolumn{3}{|c|}{ Moisture Content } \\
\hline 1 & 4.022 & \multirow{3}{*}{$\begin{array}{r}\text { Top } \\
\text { Bottom }\end{array}$} & \multirow[b]{2}{*}{3.016} & Tare No. & N/A & \multirow{3}{*}{$\begin{array}{l}\text { grams } \\
\text { grams }\end{array}$} \\
\hline 2 & 4.043 & & & Tare Weight & 0.00 & \\
\hline 3 & 4.108 & & 3.016 & Wet Weight + Tare & 1039.25 & \\
\hline \multirow[t]{2}{*}{ Average } & 4.058 & \multirow[t]{2}{*}{ Average } & \multirow[t]{2}{*}{3.016} & Dry Weight + Tare & 933.42 & \multirow{2}{*}{$\begin{array}{l}\text { grams } \\
\%\end{array}$} \\
\hline & & & & Moisture Content & 11.3 & \\
\hline
\end{tabular}

\begin{tabular}{||lll||}
\hline Total Weight of Soil + Tube Section & 1039.25 & grams \\
\cline { 2 - 2 } Weight of Clean, Dry Tube Section & 0.00 & grams \\
\cline { 2 - 2 } & Wet Weight of Soil & 2.29 \\
\cline { 2 - 3 } & $\mathrm{ft}^{3}$ \\
\hline
\end{tabular}

RESULT SUMMARY

\begin{tabular}{|c|c|c|}
\hline Moisture Content & 11.3 & $\%$ \\
\hline Wet Density & 136.6 & $p c f$ \\
\hline Dry Density & 122.7 & $p c f$ \\
\hline Specific Gravity & 2.5 & \\
\hline Porosity & 0.21 & \\
\hline
\end{tabular}

Remarks: 


\section{TP-4 UNIT WEIGHT OF SAMPLE}

Project No.: 6155-08-0031.25

Project Name: F-Area Tank Farm Grout Samples

Lab No. 11004

Tested By: $\mathrm{EH}$

Date: 09/02/11
Boring No.: LP\#8-020A

Sample No.: LP\#8-020A

Depth: N/A

Reviewed By: JW

Date: 09/26/11

\begin{tabular}{|c|c|c|c|c|c|c|}
\hline \multicolumn{2}{|c|}{$\begin{array}{l}\text { Total Sample } \\
\text { Height, inches }\end{array}$} & \multicolumn{2}{|c|}{$\begin{array}{c}\text { Inside Diameter } \\
\text { of Cut Tube, inches }\end{array}$} & \multicolumn{3}{|c|}{ Moisture Content } \\
\hline 1 & 3.026 & \multirow{3}{*}{$\begin{array}{r}\text { Top } \\
\text { Bottom }\end{array}$} & \multirow[b]{2}{*}{3.014} & Tare No. & N/A & \multirow[b]{2}{*}{ grams } \\
\hline 2 & 3.022 & & & Tare Weight & 0.00 & \\
\hline 3 & 2.986 & & 3.014 & Wet Weight + Tare & 773.12 & grams \\
\hline \multirow[t]{2}{*}{ Average } & 3.011 & \multirow[t]{2}{*}{ Average } & 3.014 & Dry Weight + Tare & 695.29 & grams \\
\hline & & & & Moisture Content & 11.2 & $\%$ \\
\hline
\end{tabular}

\begin{tabular}{||lcl||}
\hline Total Weight of Soil + Tube Section & 773.12 & grams \\
\cline { 2 - 2 } Weight of Clean, Dry Tube Section & 0.00 & grams \\
\cline { 2 - 3 } Wet Weight of Soil & $\mathrm{fts}^{3}$ \\
\cline { 2 - 3 } Volume of Sample & 0.012 & $\mathrm{ft}^{3}$ \\
\hline
\end{tabular}

RESULT SUMMARY

\begin{tabular}{|c|c|c|}
\hline Moisture Content & 11.2 & $\%$ \\
\hline Wet Density & 137.1 & $p c f$ \\
\hline Dry Density & 123.3 & $p c f$ \\
\hline Specific Gravity & 2.5 & \\
\hline Porosity & 0.21 & \\
\hline
\end{tabular}

Remarks: 


\section{ATTACHMENT 2}

Page 3 of 3 


\section{Equipment List}

SRNS Delivery Order No. 25

Subcontract No. AC54317N

\begin{tabular}{|c|c|}
\hline Equipment Name & Laboratory ID \\
\hline Oven & 109 \\
\hline Balance & 416 \\
\hline Thermometer & 2866 \\
\hline Caliper & 2424 \\
\hline Pressure Transducer & $1872 / 2908$ \\
\hline & \\
\hline & \\
\hline & \\
\hline & \\
\hline & \\
\hline & \\
\hline & \\
\hline & \\
\hline
\end{tabular}

